\title{
Hesperidin-3'-O-Methylether Is More Potent than Hesperidin in Phosphodiesterase Inhibition and Suppression of Ovalbumin-Induced Airway Hyperresponsiveness
}

\author{
You-Lan Yang, ${ }^{1}$ Hsin-Te Hsu, ${ }^{2}$ Kuo-Hsien Wang, ${ }^{3}$ Chao-Sian Wang, ${ }^{4}$ \\ Chien-Ming Chen, ${ }^{5}$ and Wun-Chang Ko ${ }^{2,4}$ \\ ${ }^{1}$ School of Respiratory Therapy, College of Medicine, Taipei Medical University, Taipei 110, Taiwan \\ ${ }^{2}$ Department of Otolaryngology, Taipei Medical University Hospital, Taipei 110, Taiwan \\ ${ }^{3}$ Department of Dermatology, Taipei Medical University Hospital, Taipei 110, Taiwan \\ ${ }^{4}$ Department of Pharmacology, College of Medicine, Taipei Medical University, Taipei 110, Taiwan \\ ${ }^{5}$ Department of Medical Technology, College of Medicine, Taipei Medical University, Taipei 110, Taiwan \\ Correspondence should be addressed to Wun-Chang Ko, wc_ko@tmu.edu.tw
}

Received 18 May 2012; Accepted 27 August 2012

Academic Editor: Wagner Vilegas

Copyright (๑) 2012 You-Lan Yang et al. This is an open access article distributed under the Creative Commons Attribution License, which permits unrestricted use, distribution, and reproduction in any medium, provided the original work is properly cited.

Hesperidin is present in the traditional Chinese medicine, "Chen $\mathrm{Pi}$," and recently was reported to have anti-inflammatory effects. Therefore, we were interested in comparing the effects of hesperidin and hesperidin-3'-O-methylether on phosphodiesterase inhibition and airway hyperresponsiveness (AHR) in a murine model of asthma. In the present results, hesperidin-3'-Omethylether, but not hesperidin, at $30 \mu \mathrm{mol} / \mathrm{kg}$ (p.o.) significantly attenuated the enhanced pause $\left(P_{\text {enh }}\right)$ value, suppressed the increases in numbers of total inflammatory cells, macrophages, lymphocytes, neutrophils, and eosinophils, suppressed total and OVA-specific immunoglobulin (Ig)E levels in the serum and BALF, and enhanced the level of total $\operatorname{IgG}_{2 \mathrm{a}}$ in the serum of sensitized and challenged mice, suggesting that hesperidin-3'-O-methylether is more potent than hesperidin in suppression of AHR and immunoregulation. The different potency between them may be due to their aglycons, because these two flavanone glycosides should be hydrolyzed by $\beta$-glucosidase after oral administration. Neither influenced xylazine/ketamine-induced anesthesia, suggesting that they may have few or no adverse effects, such as nausea, vomiting, and gastric hypersecretion. In conclusion, hesperidin-3'-O-methylether is more potent in phosphodiesterase inhibition and suppression of AHR and has higher therapeutic $\left(\mathrm{PDE} 4_{H} / \mathrm{PDE}_{L}\right)$ ratio than hesperidin. Thus, hesperidin-3'-O-methylether may have more potential for use in treating allergic asthma and chronic obstructive pulmonary disease.

\section{Introduction}

Phosphodiesterases (PDEs) are classified according to their primary protein and complementary (c)DNA sequences, cofactors, substrate specificities, and pharmacological roles. It is now known that phosphodiesterases (PDEs) comprise at least 11 distinct enzyme families that hydrolyze adenosine $3^{\prime}, 5^{\prime}$ cyclic monophosphate (cAMP) and/or guanosine $3^{\prime}, 5^{\prime}$ cyclic monophosphate (cGMP) [1]. PDE1 5 isozymes, which are calcium/calmodulin dependent (PDE1), cGMP stimulated (PDE2), cGMP inhibited (PDE3), cAMP specific (PDE4), and cGMP specific (PDE5), were found to be present in the canine trachea [2], guinea pig lungs [3], and human bronchi [4]. PDE3 and PDE4 were identified in the guinea pig airway [5], but other isozymes might also be present. PDE4 may adopt two different conformations which have high $\left(\mathrm{PDE} 4_{H}\right)$ and low $\left(\mathrm{PDE} 4_{L}\right)$ affinities for rolipram, respectively. It is believed that inhibition of $\mathrm{PDE}_{H}$ is associated with adverse responses, such as nausea, vomiting, and gastric hypersecretion, while inhibition of $\mathrm{PDE}_{L}$ is associated with anti-inflammatory and bronchodilating effects. Therefore the therapeutic ratio of selective PDE4 inhibitors for use in treating asthma and chronic obstructive pulmonary disease $(\mathrm{COPD})$ is defined as the $\mathrm{PDE} 4_{H} / \mathrm{PDE} 4_{L}$ 
ratio $[6,7]$. Although both asthma and COPD are associated with an underlying chronic inflammation of the airways, there are important differences with regard to the inflammatory cells and mediators involved. The key inflammatory cells in COPD are macrophages, CD8+ T-lymphocytes, and neutrophils. In contrast, the key inflammatory cells in asthma are mast cells, eosinophils, and CD4+ T-lymphocytes. Both diseases are sensitive to steroids. However, COPD shows a limited response to inhaled corticosteroids as compared to the efficacy achieved in asthma. Other therapeutic drugs such as selective PDE4 or dual PDE3/4 inhibitors are recently developing. However, these developing inhibitors are also limited for the use of asthma and COPD in clinic because of their emetic side effect. This side effect can be easily assessed in nonvomiting species, such as rats or mice, in which selective PDE4 inhibitors reduce the duration of xylazine/ketamine-induced anesthesia $[8,9]$.

Hesperetin, one of the most-common flavonoids in Citrus, was reported to selectively inhibit PDE4 activity [10]. Men with higher hesperetin intake have lower mortality from cerebrovascular disease and lung cancer, and lower incidences of asthma [11]. Hesperetin frequently occurs in nature as glycosides, such as hesperidin and neohesperidin. They are abundantly present in the fruit peel of Citrus aurantium L. (Rutaceae), a well-known traditional Chinese medicine called "Chen-Pi", which is used as an expectorant and stomach tonic, and contains vitamin $\mathrm{P}$, a remedy for preventing capillary fragility and hypertension [12]. These glycosides are easily hydrolyzed by glycosidase to form hesperetin after ingestion. Hesperidin was recently reported to inhibit inflammatory cell infiltration and mucus hypersecretion in a murine model of asthma [13]. Therefore, we were interested in comparing the effects of hesperidin and hesperidin-3'-O-methylether, a more-liposoluble derivative of hesperidin, on PDE1 5 inhibition and suppression on ovalbumin-induced airway hyperresponsiveness (AHR). To clarify their potentials for use in treating asthma and COPD, their $\mathrm{PDE} 4_{H} / \mathrm{PDE} 4_{L}$ ratios were also investigated.

\section{Materials and Methods}

2.1. Reagents and Animals. Hesperidin (mol wt., 610.60) and hesperidin-3'-O-methylether (mol wt., 624.59) were purchased from Sigma Chemical (St. Louis, MO, USA) and Tokyo Chemical Industry (Tokyo, Japan), respectively. Their structures are shown in Figure 1. From Sigma Chemical, ovalbumin, methacholine, aluminum sulfate hexadecahydrate, dimethylsulfoxide (DMSO), chloralose, urethane, Tris- $\mathrm{HCl}$, Bis-Tris, benzamidine, phenylmethanesulfonyl fluoride (PMSF), d,l-dithiothreitol, polyethyleneimine, ethylenediaminetetraacetic acid (EDTA), bovine serum albumin (BSA), cAMP, cGMP, calmodulin, Dowex resin, Crotalus atrox snake venom, xylazine, and ketamine were also purchased. Vinpocetine, erythro-9-(2-hydroxy3-nonyl)-adenine $\mathrm{HCl}$ (EHNA), milrinone, 4-(3-butoxy4-methoxybenzyl)-2-imidazolidinone (Ro 20-1724), and zaprinast were purchased from Biomol (Plymouth Meeting, PA, USA). Mouse T helper (Th)1/Th2 cytokine CBA kits and mouse IgE enzyme-linked immunosorbent assay

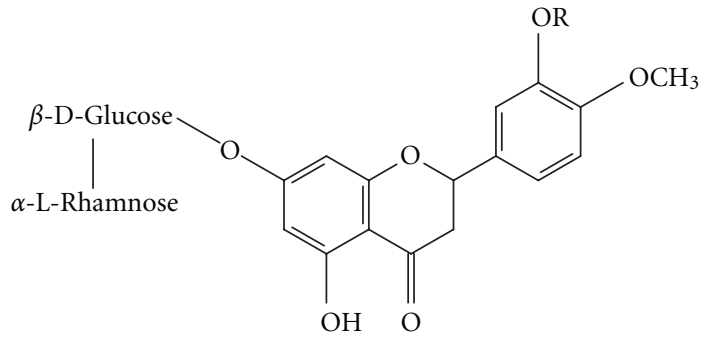

Compound name

$\mathrm{R}$

(a) Hesperidin

$\mathrm{H}$

(b) Hesperidin-3'-O-methylether $\mathrm{CH}_{3}$

Figure 1: The structures of hesperidin (a) and hesperidin- $3^{\prime}-O-$ methylether (b).

(ELISA) sets were purchased from Pharmingen (San Diego, CA, USA). Ethyl alcohol and polyethylene glycol (PEG) 400 were purchased from Merck (Darmstadt, Germany). $\left[{ }^{3} \mathrm{H}\right]$-cAMP, $\left[{ }^{3} \mathrm{H}\right]$-cGMP, and $\left[\right.$ methyl- $\left.{ }^{3} \mathrm{H}\right]$-rolipram were purchased from Amersham Pharmacia Biotech (Buckinghamshire, UK). Other reagents, such as $\mathrm{CaCl}_{2}, \mathrm{MgCl}_{2}$, and $\mathrm{NaCl}$, were of analytical grade. Hesperidin, hesperidin- $3^{\prime}-$ O-methylether, milrinone, Ro 20-1724, and zaprinast were dissolved in DMSO. Vinpocetine, EHNA, and PMSF were dissolved in 95\% ethyl alcohol. Other reagents were dissolved in distilled water.

Male Dunkin Hartley guinea pigs $(500 \sim 600 \mathrm{~g})$, and female BABL/c mice at $8 \sim 12$ weeks old were purchased from the Animal Center of the National Science Council (Taipei, Taiwan), and housed in ordinary cages at $22 \pm 1^{\circ} \mathrm{C}$ with a humidity of $50 \% \sim 60 \%$ under a constant $12 / 12$-h light/dark cycle and provided with food and water ad libitum. Under a protocol approved by the Animal Care and Use Committee of Taipei Medical University, the following in vivo and in vitro experiments were performed.

2.2. Inhibition of PDE1, PDE3, and PDE4 Activities by Hesperidin-3'-O-Methylether. Activities of PDE1 5 in the homogenate of guinea pig lungs or hearts [14] were measured by a two-step procedure according to the previous method [15], using cAMP with $\left[{ }^{3} H\right]$-cAMP or cGMP with $\left[{ }^{3} \mathrm{H}\right]$-cGMP as substrates. The enzyme preparation $(25 \mu \mathrm{L})$ was incubated for $30 \mathrm{~min}$ at $37^{\circ} \mathrm{C}$ in a total assay volume of $100 \mu \mathrm{L}$ containing $50 \mathrm{mM}$ Tris- $\mathrm{HCl}$ ( $\mathrm{pH}$ 7.4), $3 \mathrm{mM}$ $\mathrm{MgCl}_{2}, 1 \mathrm{mM}$ dithiothreitol, $0.05 \% \mathrm{BSA}$, and $1 \mu \mathrm{M}$ cAMP with $0.2 \mu \mathrm{Ci}\left[{ }^{3} \mathrm{H}\right]$-cAMP as a substrate alone or in the presence of 0.1 unit calmodulin with $10 \mu \mathrm{M} \mathrm{CaCl}_{2}$ or $5 \mu \mathrm{M}$ cGMP, and $1 \mu \mathrm{M}$ cGMP with $0.2 \mu \mathrm{Ci}\left[{ }^{3} \mathrm{H}\right]-\mathrm{cGMP}$ as another substrate alone or in the presence of 0.1 unit calmodulin with $10 \mu \mathrm{M} \mathrm{CaCl}_{2}$. The reaction mixture contained $10 \mu \mathrm{L}$ of vehicle or test compounds including hesperidin, hesperidin$3^{\prime}$-O-methylether, or selective PDE1 5 inhibitors, such as vinpocetine [16], EHNA [17], milrinone [18], Ro 20-1724 [19], and zaprinast [20] as reference drugs. The reagents and homogenate were mixed on ice, and the reaction was 


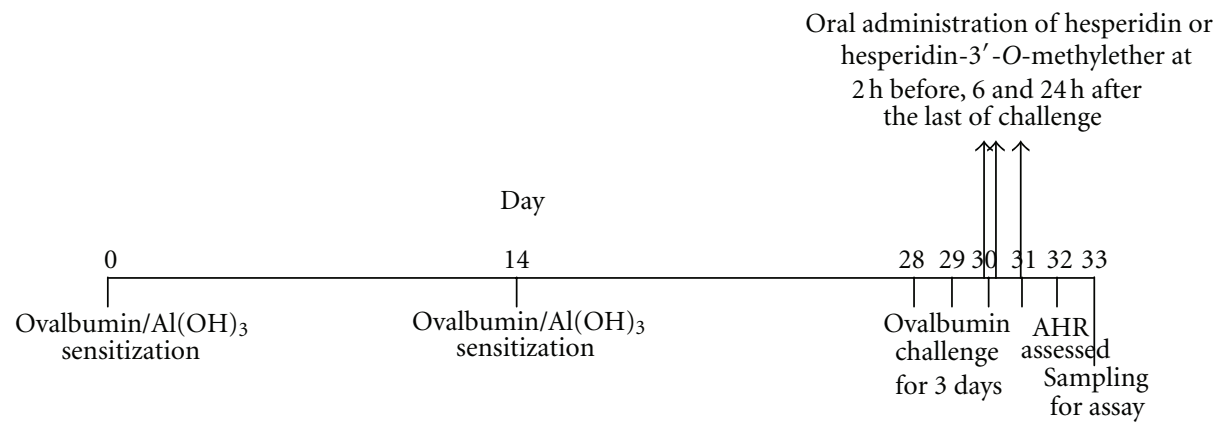

FIGURE 2: The schedule of sensitization, challenge, and drug administration in mice. AHR airway hyperresponsiveness; $\mathrm{Al}(\mathrm{OH})_{3}:$ aluminum hydroxide gel.

initiated by transferring the mixture to a water bath at $37^{\circ} \mathrm{C}$. Following a $30 \mathrm{~min}$ incubation, the reaction was stopped by transferring the reaction vessel to a bath of boiling water for $3 \mathrm{~min}$. After cooling on ice, $20 \mu \mathrm{L}$ of a $1 \mathrm{mg} / \mathrm{mL}$ solution of Crotalus atrox snake venom was added to the reaction mixture, and the mixture was incubated at $37^{\circ} \mathrm{C}$ for $10 \mathrm{~min}$. Unreacted $\left[{ }^{3} \mathrm{H}\right]$-cAMP or $\left[{ }^{3} \mathrm{H}\right]$-cGMP was removed by the addition of $500 \mu \mathrm{L}$ of a 1-in-1 Tris- $\mathrm{HCl}(40 \mathrm{mM})$ buffer suspension of Dowex resin $(1 \times 2-400)$ with incubation on ice for $30 \mathrm{~min}$. Each tube was then centrifuged at $3700 \mathrm{~g}$ for $2 \mathrm{~min}$, and $100 \mu \mathrm{L}$ of the supernatant was removed for liquid scintillation counting. Less than $10 \%$ of the tritiated cyclic nucleotide was hydrolyzed in this assay.

2.3. Determination of $P D E 4_{H}$ Values. When the abovementioned guinea pigs were sacrificed, the whole brains were removed and homogenized with a glass/Teflon homogenizer (Glas-Col, Terre Haute, IN, USA) in 10 volumes of cold medium ( $\mathrm{pH}$ 6.5) containing $20 \mathrm{mM}$ Bis-Tris, $2 \mathrm{mM}$ benzamidine, $2 \mathrm{mM}$ EDTA, $50 \mathrm{mM}$ sodium chloride, $0.1 \mathrm{mM}$ PMSF, and $1 \mathrm{mM}$ dithiothreitol. At $4^{\circ} \mathrm{C}$, the homogenate was centrifuged at $170 \mathrm{~g}$ for $5 \mathrm{~min}$ to remove connective tissues and blood vessels. The suspended homogenate was then recentrifuged at $40,000 \mathrm{~g}$ for $30 \mathrm{~min}$ to separate the cytosolic and particulate portions. The particulate portion was resuspended in a suspension at a concentration of $400 \mathrm{mg} / \mathrm{mL}$ (wet weight/volume), after washing three times with homogenizing buffer. The particulate portion mainly consisted of cell membranes. The binding ability of hesperidin $(300 \mu \mathrm{M})$ or hesperidin-3' $-O$-methylether (3 $300 \mu \mathrm{M})$ to high-affinity rolipram-binding sites (HARBSs) of membranes was determined by replacing $2 \mathrm{nM}\left[{ }^{3} \mathrm{H}\right]$ rolipram in a reaction buffer at $30^{\circ} \mathrm{C}$ for $1 \mathrm{~h}$, according to the method described by previous investigators [21, 22] and modified by us. Briefly, the reaction buffer consisted of $50 \mathrm{mM}$ Tris- $\mathrm{HCl}$ and $5 \mathrm{mM} \mathrm{MgCl} 2(\mathrm{pH} \mathrm{7.5)}$. The total volume of the reaction mixture was $25 \mu \mathrm{L}$, consisting of $10 \mu \mathrm{L}$ of the particulate suspension, $10 \mu \mathrm{L}$ of $\left[{ }^{3} \mathrm{H}\right]$-rolipram, and $5 \mu \mathrm{L}$ of hesperidin, hesperidin-3'-O-methylether, or reference drug, such as Ro 20-1724 (1 10,000 nM). After $1 \mathrm{~h}$, the reaction was terminated by moving the reaction vessel into crushed ice. Then the reaction mixture was transferred onto Whatman GF/B glass-fiber filters, which were soaked in a $0.3 \%$ polyethyleneimine solution in a mini-funnel. The reaction mixture was filtered by centrifugation at $90 \mathrm{~g}$ for $10 \mathrm{~s}$, and the filtrate was collected into a 1.5-mL Eppendorf tube with the top adapted to the outlet of the mini-funnel. The filters were washed with $300 \mu \mathrm{L}$ of the reaction buffer three times each in the same way and transferred into $2 \mathrm{~mL}$ of cocktail for radiation counting (total binding) using a $\beta$-scintillation counter (Beckman, Fullerton, CA, USA). Nonspecific binding, which was defined in the presence of $10 \mu \mathrm{M}$ Ro 20-1724, was subtracted from total binding to yield specific binding. Effective concentration $\left(\mathrm{EC}_{50}\right)$ values of hesperidin, hesperidin-3'-O-methylether, and Ro 20-1724, at which a half of the $\left[{ }^{3} \mathrm{H}\right]$-rolipram that was bound onto HARBSs of cell membranes was displaced, were defined as $\mathrm{PDE}_{H}$ values, and these were related to any adverse effects, such as nausea, vomiting, and gastric hypersecretion [7].

2.4. AHR In Vivo. According to the schedule (Figure 2), ten female $\mathrm{BABL} / \mathrm{c}$ mice in each group were sensitized by an intraperitoneal (i.p.) injection of $20 \mu \mathrm{g}$ of ovalbumin emulsified in $2.25 \mathrm{mg}$ of an aluminum hydroxide gel, prepared from aluminum sulfate hexadecahydrate, in a total volume of $100 \mu \mathrm{L}$ on days 0 and 14 . Mice were challenged via the airway using $1 \%$ ovalbumin in saline for $30 \mathrm{~min}$ on days 28, 29, and 30 by ultrasonic nebulization. After the last ovalbumin challenge [23], AHR was assessed on day 32 ( $48 \mathrm{~h}$ after $1 \%$ ovalbumin provocation) in each group. Each group of mice was orally (p.o.) administered the vehicle (control), 30 100 $\mu \mathrm{mol} / \mathrm{kg}$ of hesperidin or $10 \sim$ $100 \mu \mathrm{mol} / \mathrm{kg}$ of hesperidin-3'-O-methylether $2 \mathrm{~h}$ before and 6 and $24 \mathrm{~h}$ after ovalbumin provocation. For comparison, sham-treated mice were challenged with saline instead of $1 \%$ ovalbumin (nonchallenged). The vehicle, a mixture of DMSO:PEG $400:$ saline $(1: 1: 8, \mathrm{v} / \mathrm{v})$, hesperidin, or hesperidin-3'-O-methylether was administered (p.o.) at a volume of $0.01 \mathrm{~mL} / \mathrm{g}$ of body weight. AHR was assessed by barometric plethysmography [24] using a whole-body plethysmograph (WBP) and analyzed using software of Life Science Suite P3 Analysis Modules (Gould, LDS Test and Measurement LLC, Valley View, OH, USA) in unrestrained animals. Mice were placed into the main chamber of the WBP, and the baseline enhanced pause $\left(P_{\text {enh }}\right)$ value was determined. Then mice were first nebulized with phosphatebuffered saline (PBS), and subsequently with increasing doses $(6.25 \sim 50 \mathrm{mg} / \mathrm{mL})$ of methacholine for $3 \mathrm{~min}$ for each 
nebulization, followed by readings of breathing parameters for 3 min after each nebulization to determine $P_{\text {enh }}$ values. Twenty-four hours after $P_{\text {enh }}$ determination, these mice were anesthetized with pentobarbital $(50 \mathrm{mg} / \mathrm{kg}$, i.p.), and the lungs were lavaged via a tracheal tube with PBS $(1 \times$ $1.0 \mathrm{~mL}, 37^{\circ} \mathrm{C}$ ). After lavage, blood was collected from the jugular vein and allowed to sit so that it would coagulate. The collected bronchoalveolar lavage fluid (BALF) and coagulated blood were respectively centrifuged at $630 \mathrm{~g}$ for $7 \mathrm{~min}$ and at $3700 \mathrm{~g}$ for $10 \mathrm{~min}$ at $4^{\circ} \mathrm{C}$. After centrifugation, the BALF and serum supernatants were stored at $-20^{\circ} \mathrm{C}$ until determinations of cytokines, including interleukin (IL)2 , IL-4, IL-5, tumor necrosis factor (TNF)- $\alpha$, and interferon (IFN)- $\gamma$ by flow cytometric methods [25] using mouse Th1/Th2 cytokine CBA kits, and of a total immunoglobulin (Ig)E and $\operatorname{IgG}_{2 \mathrm{a}}$ using ELISA kits (Pharmingen, San Diego, CA, USA) according to the respective recommendations of the manufacturers. Ovalbumin-specific IgE was measured as described previously [26]. Wells were coated with $100 \mu \mathrm{L}$ of ovalbumin $(20 \mu \mathrm{g} / \mathrm{mL})$ instead of the capture antibody. Levels are expressed in arbitrary units, where 1 arbitrary unit equals the optical density of the sample divided by the optical density of unchallenged mouse serum or BALF (standard). The BALF pellet was resuspended in ACK lysing buffer $\left(1.658 \mathrm{~g} \mathrm{NH}_{4} \mathrm{Cl}, 0.2 \mathrm{~g} \mathrm{KHCO}_{3}\right.$, and $1.44 \mathrm{mg}$ EDTA in $200 \mathrm{~mL}$ of water) to lyse the residual erythrocytes in each sample. The number of inflammatory cells was counted using a hemocytometer (Hausser Scientific, Horsham, PA, USA). Cytospin slides were stained and cell differentials were determined in a blinded fashion by counting at least 100 cells under light microscopy. All undetectable data $(<1 \mathrm{pg} / \mathrm{mL})$ of cytokines were taken as $0.5 \mathrm{pg} / \mathrm{mL}$.

2.5. Xylazine/Ketamine-Induced Anesthesia. According to a previously described method [9] and modified by us, hesperidin, hesperidin-3' -O-methylether (each $300 \mu \mathrm{mol} / \mathrm{kg}$, subcutaneously (s.c.)), or Ro 20-1724 (0.01 1 $\mu \mathrm{mol} / \mathrm{kg}$, s.c.), a reference drug, was, respectively, injected into $8 \sim 12$-weekold female BALB/c mice 1,1 or $0.25 \mathrm{~h}$ prior to an i.p. injection of xylazine $(10 \mathrm{mg} / \mathrm{kg}) / \mathrm{ketamine}(70 \mathrm{mg} / \mathrm{kg})$. The vehicle (control) for hesperidin, hesperidin-3'-O-methylether, or Ro 20-1724 was a mixture of DMSO:PEG 400 : saline $(1: 1: 8, \mathrm{v} / \mathrm{v})$. After the loss of the righting reflex (i.e., when a mouse remained on its back and no longer spontaneously righted itself to a prone position), the duration of anesthesia was measured until its return as the endpoint [9].

2.6. Statistical Analysis. All values are given as the mean \pm SEM. Differences among values were statistically calculated by one-way analysis of variance (ANOVA), and then determined by Dunnett's test. The difference between two values, however, was determined by the use of Student's $t$-test. Differences with $P<0.05$ were considered statistically significant.

\section{Results}

3.1. Inhibition of PDE1, PDE3, and PDE4 Activities by Hesperidin-3'-O-methylether. Hesperidin did not inhibit
PDE1 5 activities $\left(\mathrm{IC}_{50}>100 \mu \mathrm{M}\right)$. Similarly, hesperidin$3^{\prime}$-O-methyl ether did not inhibit PDE2 or PDE5 activity $\left(\right.$ IC $\left._{50}>100 \mu \mathrm{M}\right)$. However, its concentration-dependently inhibited PDE1, PDE3, and PDE4 activities with respective $\mathrm{IC}_{50}$ values of $13.6 \pm 2.3 \mu \mathrm{M}(n=4), 13.2 \pm 0.9 \mu \mathrm{M}(n=5)$, and $13.9 \pm 2.4 \mu \mathrm{M}(n=3)$ (Figures 3(a), 3(b), and 3(c)). The reference drugs, vinpocetine, milrinone, and Ro 20-1724, also concentration-dependently inhibited these enzymes with respective $\mathrm{IC}_{50}$ values of $30.8 \pm 1.1 \mu \mathrm{M}(n=4), 2.7 \pm$ $0.8 \mu \mathrm{M}(n=3)$, and $3.5 \pm 0.2 \mu \mathrm{M}(n=4)$ (Figures 3(d), 3(e), and $3(\mathrm{f}))$. The $\mathrm{IC}_{50}$ values of hesperidin-3'-O-methyl ether for PDE1, PDE3, and PDE4 inhibition did not significantly differ from each other.

3.2. $P D E 4_{H} / P D E 4_{L}$ Ratios. Hesperidin $(300 \mu \mathrm{M})$ displaced $2 \mathrm{nM}\left[{ }^{3} \mathrm{H}\right]$-rolipram binding on HARBSs of guinea pig brain cell membranes only $27.0 \pm 1.4 \%$ (Figure $4(\mathrm{a})$ ). In other words, the $\mathrm{EC}_{50}\left(\mathrm{PDE}_{H}\right)$ value of hesperidin was $>300 \mu \mathrm{M}$. However, hesperidin-3'-O-methylether $(3 \sim 300 \mu \mathrm{M})$, similar to Ro 20-1724 (3 300 nM), concentration-dependently displaced $2 \mathrm{nM}\left[{ }^{3} \mathrm{H}\right]$-rolipram binding on HARBSs of guinea pig brain cell membranes (Figures $4(\mathrm{a})$ and $4(\mathrm{~b})$ ). The respective $\mathrm{EC}_{50}\left(\mathrm{PDE}_{H}\right)$ values of hesperidin-3'-Omethylether, and Ro 20-1724 for displacing $\left[{ }^{3} H\right]$-rolipram binding were $218.3 \pm 32.1(n=6) \mu \mathrm{M}$ and $105.4 \pm 13.1(n=$ 6) nM. While the $\mathrm{IC}_{50}$ values of hesperidin, hesperidin- $3^{\prime}$ O-methylether, and Ro 20-1724 for inhibiting PDE4 catalytic activity were $>100,13.9$, and $3.5 \mu \mathrm{M}$, respectively, which were taken to be $P D E 4_{L}$ values. Thus, the $\mathrm{PDE} 4_{H} / \mathrm{PDE} 4_{L}$ ratios of hesperidin, hesperidin-3'-O-methylether and Ro 20-1724 were $3,15.7$, and 0.03 , respectively.

3.3. Supression of AHR In Vivo. $P_{\mathrm{enh}}$ values at the baseline for the control sensitized and challenged, nonchallenged, and 30 , and $100 \mu \mathrm{mol} / \mathrm{kg}$ hesperidin groups were $2.38 \pm 0.05$, $2.40 \pm 0.04,2.39 \pm 0.06$, and $2.41 \pm 0.04$, respectively, and these values did not significantly differ from each other. $P_{\text {enh }}$ values with PBS nebulization for each group were $2.39 \pm$ $0.06,2.41 \pm 0.04,2.40 \pm 0.05$, and $2.39 \pm 0.05$, respectively, which also did not significantly differ from each other. Administration of nebulized PBS did not affect the $P_{\text {enh }}$ value of the baseline in each group. However, methacholine (6.25 $50 \mathrm{mg} / \mathrm{mL}$ ) concentration-dependently increased $P_{\text {enh }}$ values from 1-fold with PBS exposure to $1.80 \pm 0.03$-fold in control sensitized and challenged mice (Figure 5(a)). $P_{\text {enh }}$ values of methacholine at 25 and $50 \mathrm{mg} / \mathrm{mL}$ in control sensitized and challenged mice were significantly enhanced compared to those in nonchallenged mice. Hesperidin $(100 \mu \mathrm{mol} / \mathrm{kg}$, p.o.) significantly attenuated the enhancement of $P_{\text {enh }}$ values induced by 25 and $50 \mathrm{mg} / \mathrm{mL}$ methacholine (Figure 5(a)).

Similarly, $P_{\text {enh }}$ values at the baseline for the control sensitized and challenged, nonchallenged, and 10, 30, and $100 \mu \mathrm{mol} / \mathrm{kg}$ hesperidin- $3^{\prime}-O$-methylether groups were $2.39 \pm 0.06,2.40 \pm 0.03,2.41 \pm 0.05,2.38 \pm 0.06$, and $2.41 \pm$ 0.05 , respectively, and these values did not significantly differ from each other. $P_{\text {enh }}$ values with PBS nebulization for each group were $2.40 \pm 0.04,2.38 \pm 0.05,2.41 \pm 0.06$, $2.42 \pm 0.05$, and $2.39 \pm 0.06$, respectively, which also did not significantly differ from each other. Administration 


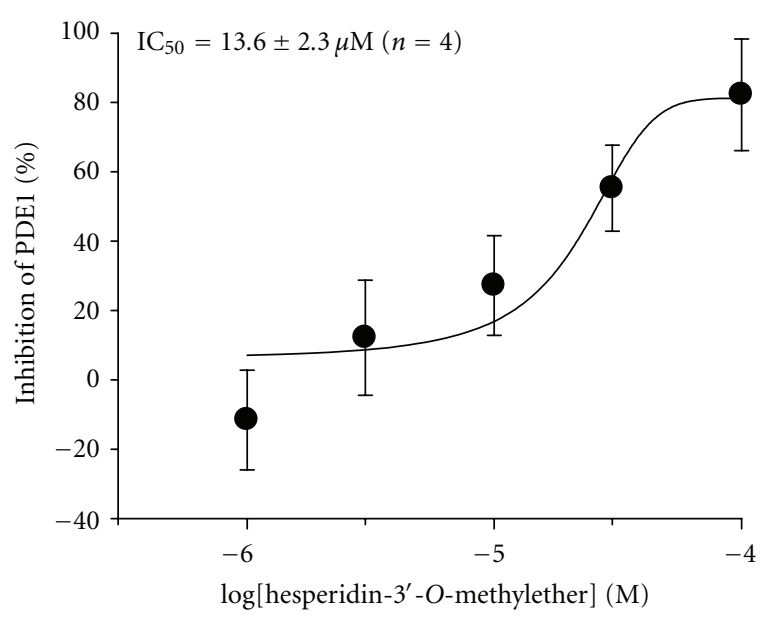

(a)

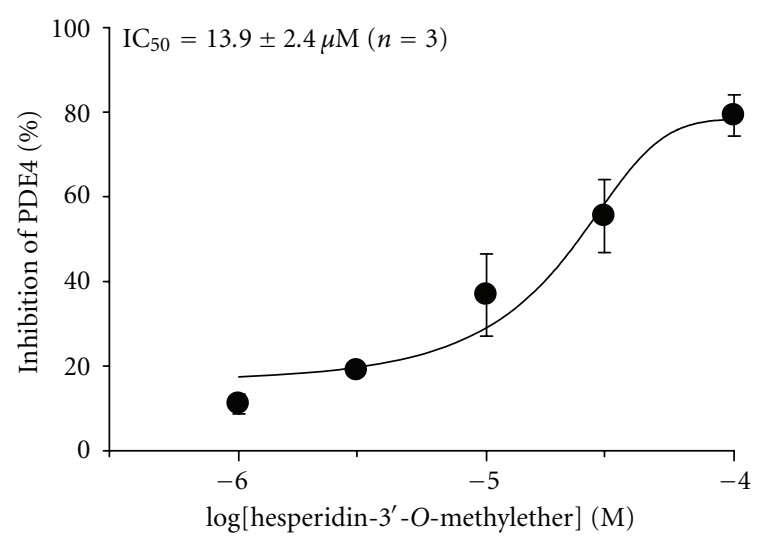

(c)

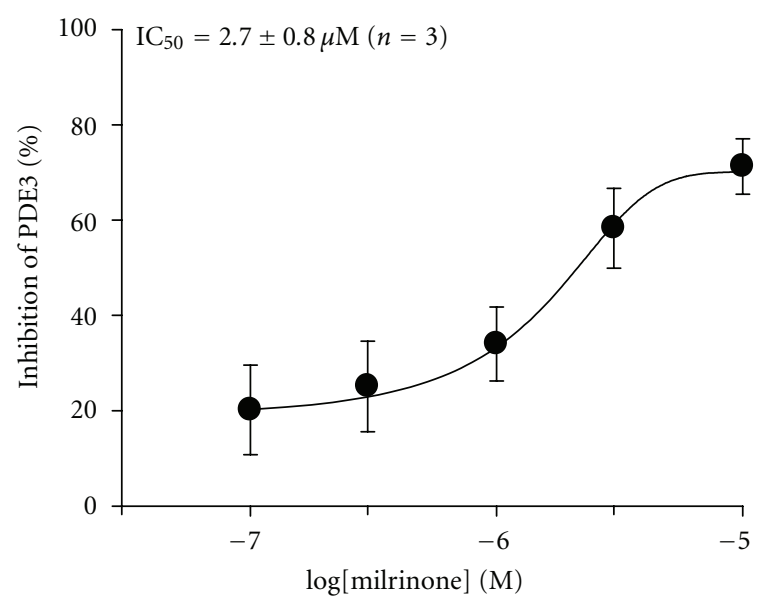

(e)

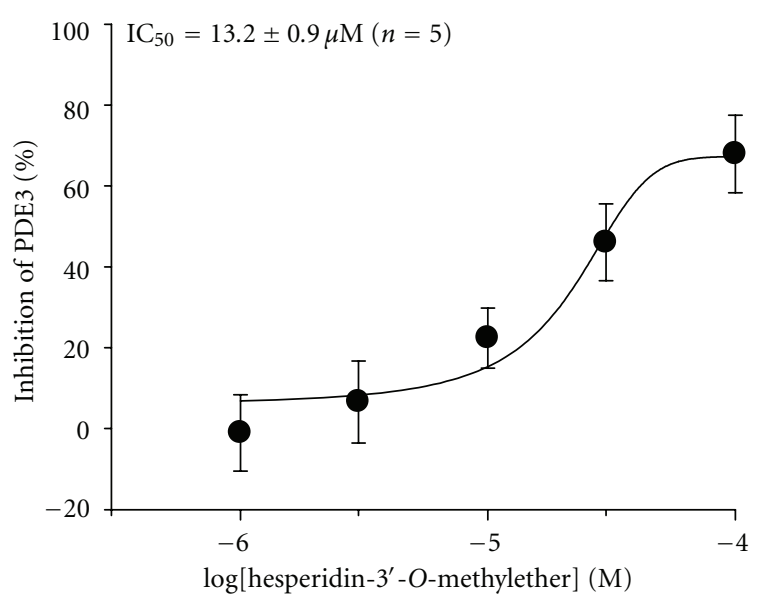

(b)

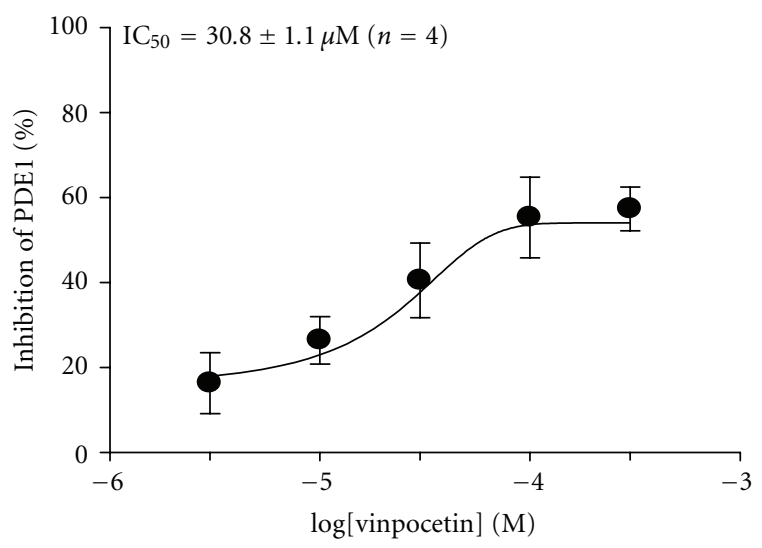

(d)

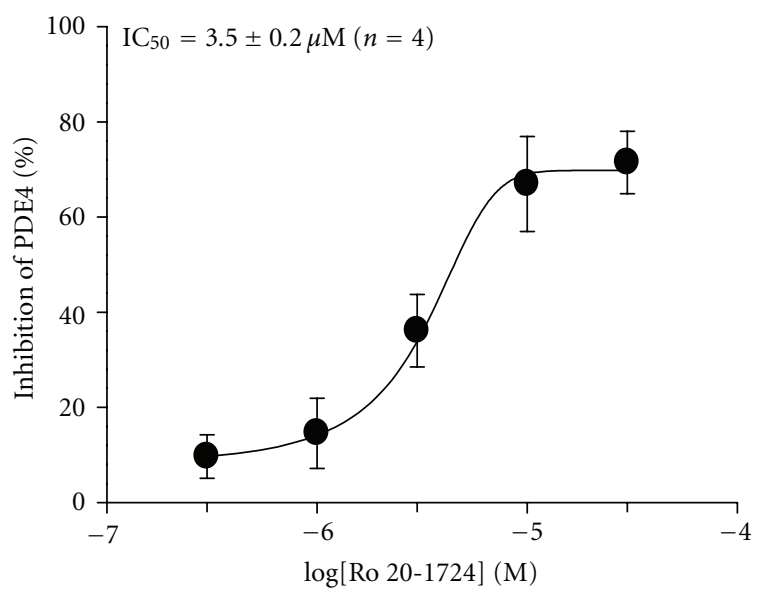

(f)

FIGURE 3: Log concentration-inhibition curves of hesperidin-3'-O-methylether ( $a, b$, and c) and reference drugs (d, e, and f) on PDE1 (a, d), PDE3 (b, e), and PDE4 (c, f) activities.

of nebulized PBS did not affect the $P_{\text {enh }}$ value of the baseline in each group. Methacholine $(6.25 \sim 50 \mathrm{mg} / \mathrm{mL})$ also concentration-dependently increased $P_{\text {enh }}$ values from 1fold with PBS exposure to $2.04 \pm 0.08$-fold in control sensitized and challenged mice (Figure 5(d)). $P_{\text {enh }}$ values of methacholine at 25 and $50 \mathrm{mg} / \mathrm{mL}$ in control sensitized and challenged mice were significantly enhanced compared to those in nonchallenged mice. Hesperidin-3'-O-methyl 


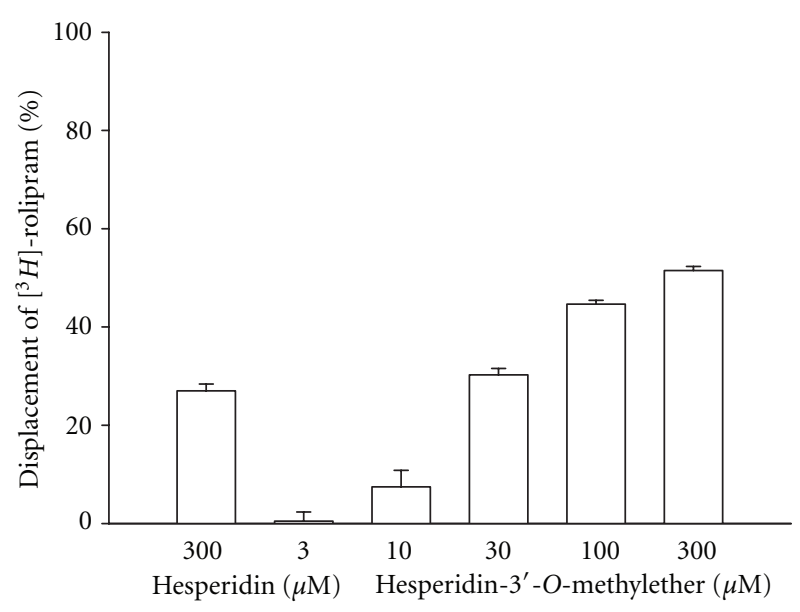

(a)

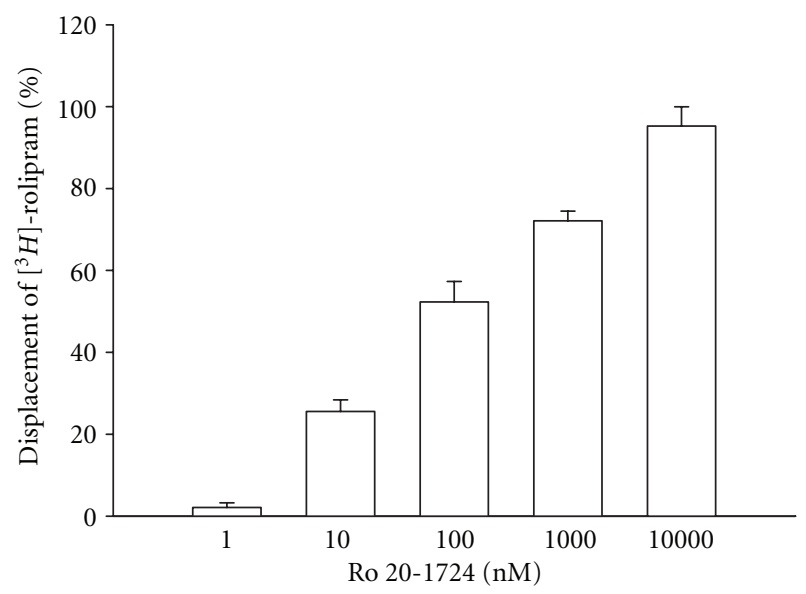

(b)

Figure 4: Displacement of $\left[{ }^{3} \mathrm{H}\right]$-rolipram by hesperidin and hesperidin-3'-O-methylether (a) and Ro 20-1724 (b) in highaffinity rolipram binding sites of guinea pig brain particulate. Each value represents the mean \pm SEM The experimental number was 6 .

ether $(30 \sim 100 \mu \mathrm{mol} / \mathrm{kg}$, p.o.) significantly attenuated the enhancement of $P_{\text {enh }}$ values induced by 25 and $50 \mathrm{mg} / \mathrm{mL}$ methacholine (Figure 5(d)).

3.4. Supression of Inflammatory Cells in BALF. The numbers of total inflammatory cells, macrophages, lymphocytes, neutrophils, and eosinophils from the BALF of control sensitized and challenged mice significantly increased compared to those of nonchallenged mice (Figure 5(b)). Hesperidin (100 $\mu \mathrm{mol} / \mathrm{kg}$, p.o.) significantly suppressed the increases in numbers of total inflammatory cells, macrophages, lymphocytes, neutrophils, and eosinophils (Figure 5(b)).

The numbers of total inflammatory cells, macrophages, lymphocytes, neutrophils, and eosinophils from the BALF of control sensitized and challenged mice also significantly increased compared to those of nonchallenged mice (Figure 5(e)). Hesperidin-3'-O-methylether $(30 \sim 100 \mu \mathrm{mol} /$ $\mathrm{kg}$, p.o.) significantly suppressed the increases in numbers of total inflammatory cells, macrophages, lymphocytes, neutrophils, and eosinophils (Figure 5(e)).
3.5. Effects on Cytokines in BALF. Compared to those in nonchallenged mice, levels of cytokines, such as IL-2, IL-4, IL-5, IFN- $\gamma$, and TNF- $\alpha$, in the BALF of control sensitized and challenged mice significantly increased (Figure 5(c)). Hesperidin $(30 \sim 100 \mu \mathrm{mol} / \mathrm{kg}$, p.o. $)$ significantly suppressed the increases in levels of IL-2, IL-4, IL-5, and TNF- $\alpha$ with the exception of TNF- $\alpha$ at a dose of $30 \mu \mathrm{mol} / \mathrm{kg}$ (Figure $5(\mathrm{c})$ ). However, hesperidin at a dose of $100 \mu \mathrm{mol} / \mathrm{kg}$ significantly enhanced the level of IFN- $\gamma$ compared to the control (Figure 5(c)).

Compared to those in nonchallenged mice, levels of cytokines, such as IL-2, IL-4, IL-5, IFN- $\gamma$, and TNF- $\alpha$, in the BALF of control sensitized and challenged mice also significantly increased (Figure 5(f)). Hesperidin-3' $-O$ methylether $(10 \sim 100 \mu \mathrm{mol} / \mathrm{kg}$, p.o.) significantly suppressed increases in levels of IL-2, IL-4, IL-5, and TNF- $\alpha$ with the exception of IL-5 at a dose of $10 \mu \mathrm{mol} / \mathrm{kg}$ (Figure 5(f)). However, hesperidin- $3^{\prime}-O$-methylether at a dose of $100 \mu \mathrm{mol} / \mathrm{kg}$ significantly enhanced the level of IFN- $\gamma$ compared to the control (Figure 5(f)).

3.6. Effects on $I_{g G_{2 a}}$ and $I g E$ in the Serum and BALF. Levels of total and ovalbumin-specific IgE in the BALF and serum of control sensitized and challenged mice were significantly enhanced compared to those of nonchallenged mice. Hesperidin $(100 \mu \mathrm{mol} / \mathrm{kg}$, p.o. $)$ significantly suppressed these enhancements (Figures 6(a), 6(b), 6(c), and 6(d)). The total $\mathrm{IgG}_{2 \mathrm{a}}$ level in the serum of control sensitized and challenged mice was significantly reduced compared to that of nonchallenged mice. Hesperidin $(100 \mu \mathrm{mol} / \mathrm{kg}$, p.o. $)$ significantly reversed this reduction (Figure $6(\mathrm{e})$ ).

Levels of total and ovalbumin-specific IgE in the serum and BALF of control sensitized and challenged mice were also significantly enhanced compared to those of nonchallenged mice. Hesperidin-3' -O-methylether $(30 \sim 100 \mu \mathrm{mol} / \mathrm{kg}$, p.o. $)$ dose-dependently and significantly suppressed these enhancements (Figures 6(f), 6(g), 6(h), and 6(i)). The total $\mathrm{IgG}_{2 \mathrm{a}}$ level in the serum of control sensitized and challenged mice was significantly reduced compared to that of nonchallenged mice. Hesperidin-3'-O-methylether $(30 \sim 100 \mu \mathrm{mol} / \mathrm{kg}$, p.o.) dose-dependently and significantly reversed this reduction (Figure $6(\mathrm{j})$ ).

3.7. No Effect on Xylazine/Ketamine-Induced Anesthesia. The durations of xylazine/ketamine-induced anesthesia in control (vehicle) mice for the hesperidin- or hesperidin-3' $-O$ methylether-, and Ro 20-1724-treated groups were $24.2 \pm$ $3.8(n=10)$, and $24.1 \pm 2.8 \mathrm{~min}(n=10)$, respectively. Neither hesperidin nor hesperidin-3'-O-methylether (each $300 \mu \mathrm{mol} / \mathrm{kg}$, s.c.) influenced the duration (Figure 7(a)). In contrast, Ro 20-1724 (0.01 1 $\mu \mathrm{mol} / \mathrm{kg}$, s.c.) dose-dependently shortened the duration and at doses of $0.03 \sim 1 \mu \mathrm{mol} / \mathrm{kg}$ (s.c.) significantly shortened the duration (Figure 7(b)).

\section{Discussion}

Allergic asthma is a chronic respiratory disease characterized by AHR, mucus hypersecretion, bronchial inflammation, 


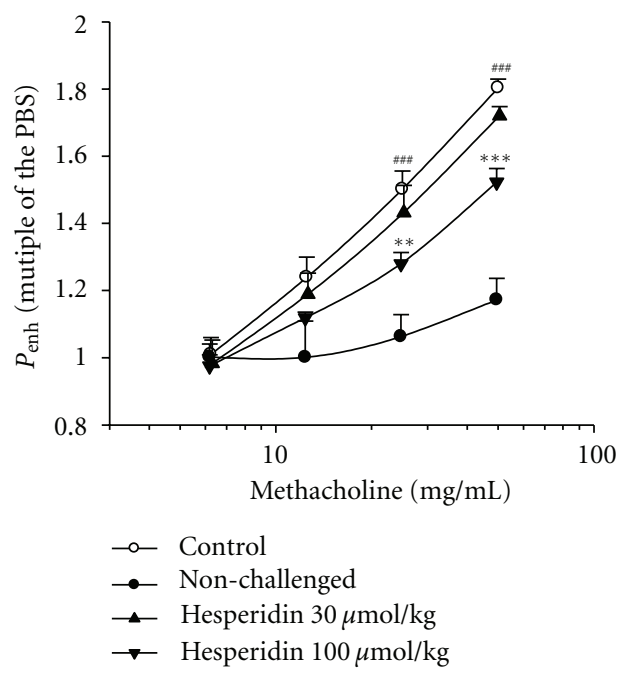

(a)

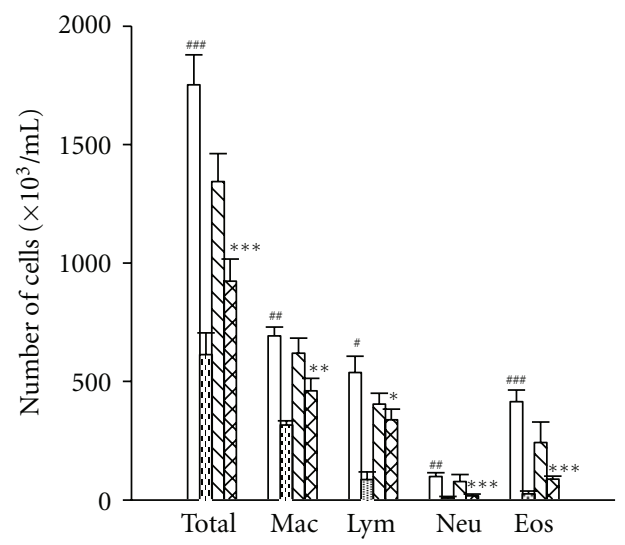

(b)

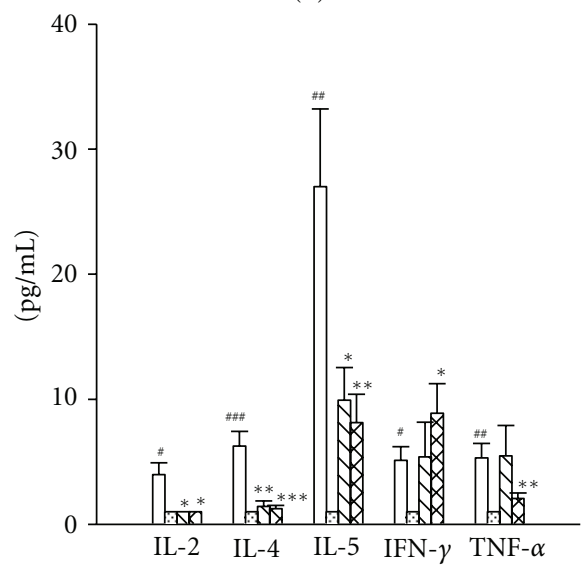

(c)

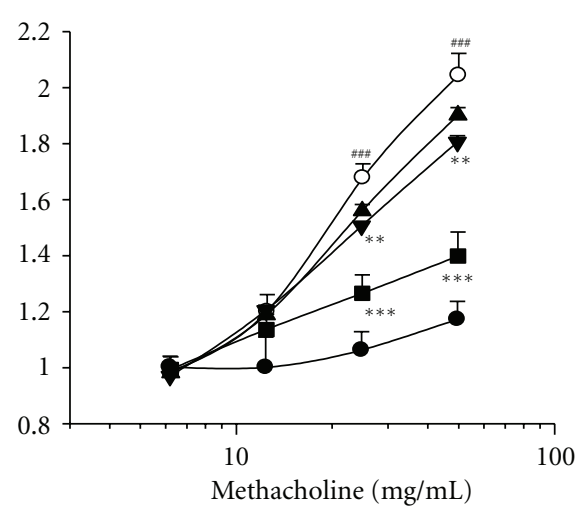

$-\infty$ Control

$\rightarrow \quad$ Non-challenged

$\sim$ Hesperidin-3'-O-methylether $10 \mu \mathrm{mol} / \mathrm{kg}$

$\rightarrow$ Hesperidin-3'-O-methylether $30 \mu \mathrm{mol} / \mathrm{kg}$

$\rightarrow$ Hesperidin-3'-O-methylether $100 \mu \mathrm{mol} / \mathrm{kg}$

(d)

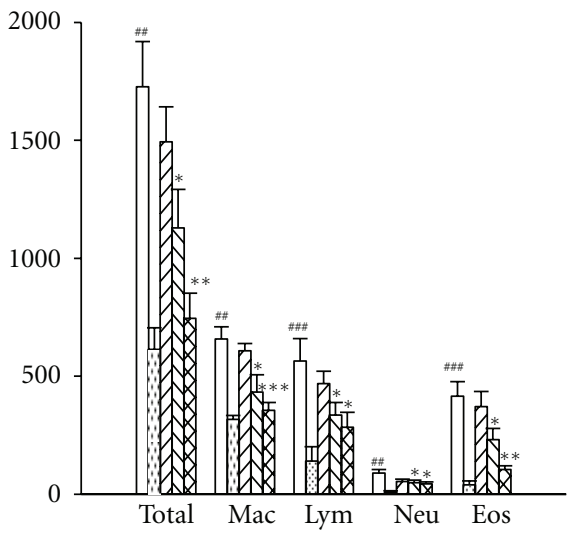

(e)

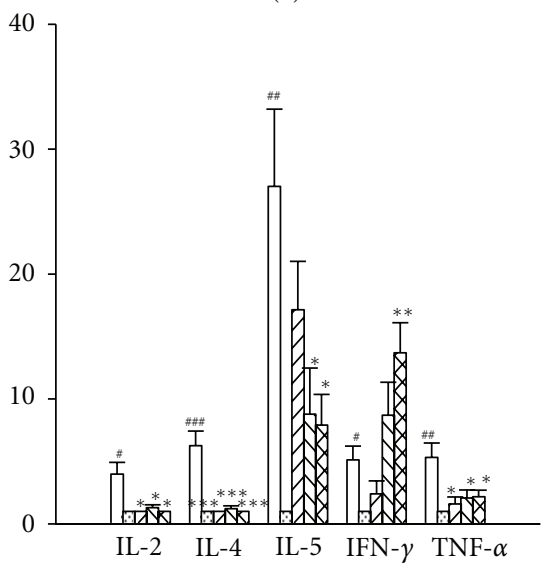

(f)

FIGURE 5: Effects of orally administered hesperidin (a, b, and c) and hesperidin- $3^{\prime}-O$-methylether $(\mathrm{d}, \mathrm{e}$, and $\mathrm{f})$ on the enhanced pause $\left(P_{\text {enh }}\right.$, a, d), inflammatory cells (b, e), and cytokines (c, f) in sensitized mice which received aerosolized methacholine $(6.25 \sim 50 \mathrm{mg} / \mathrm{mL}) 2 \mathrm{days}$ after the last allergen challenge. ${ }^{\#} P<0.05$, ${ }^{\# \#} P<0.01$, and ${ }^{\# \# \#} P<0.001$, compared to the nonchallenged group. ${ }^{*} P<0.05$, ${ }^{* *} P<0.01$, and ${ }^{* * *} P<0.001$, compared to the control (vehicle) group. The number of mice in each group was 10. Total, total cells; Mac: macrophages; Lym: lymphocytes; Neu: neutrophils; Eos: eosinophils; IL: interleukin; IF: interferon; TNF: tumor necrosis factor. 


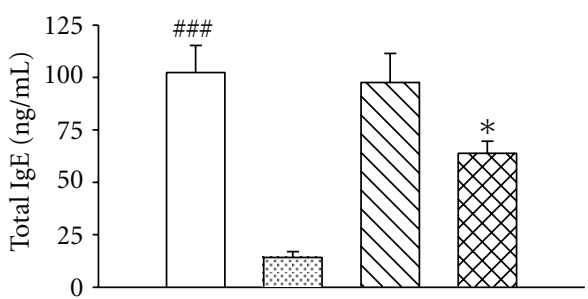

(a)

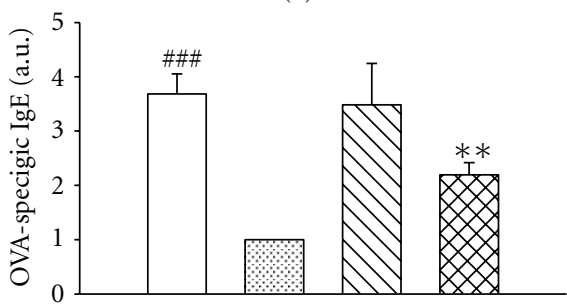

(b)

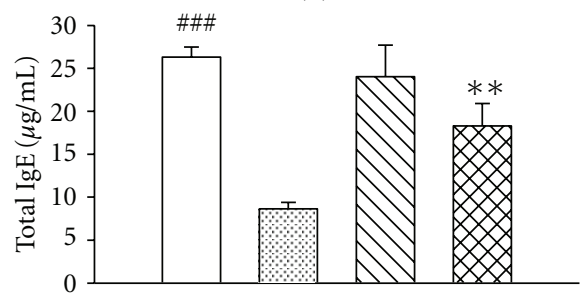

(c)

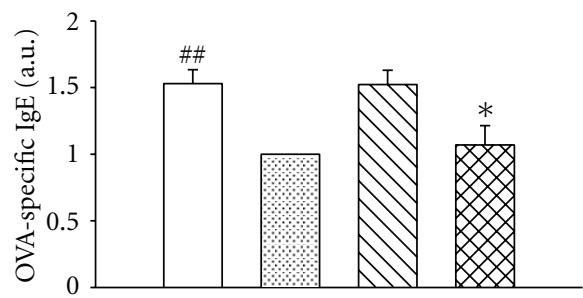

(d)

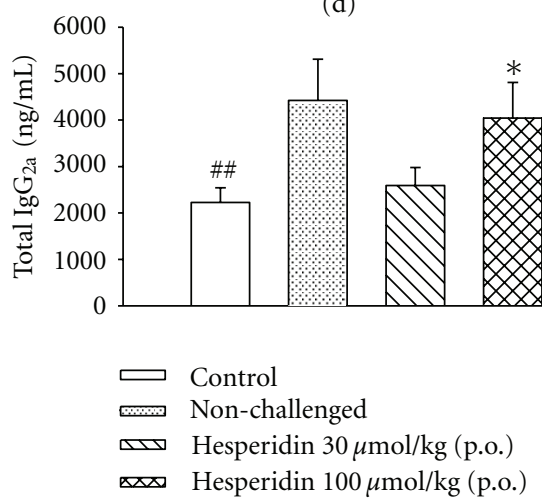

(e)

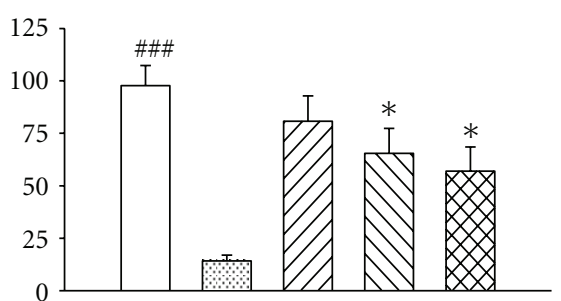

(f)

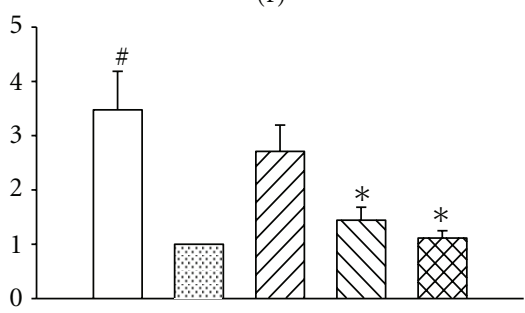

(g)

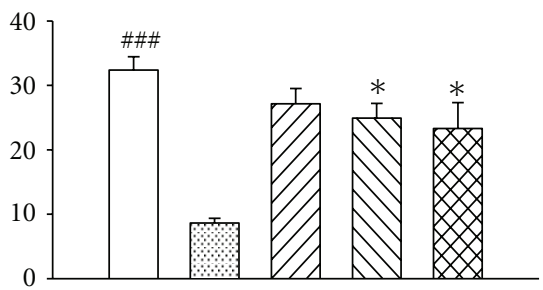

(h)

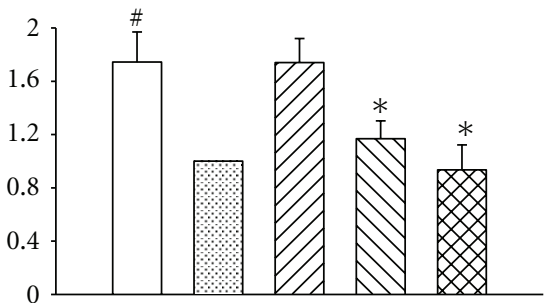

(i)

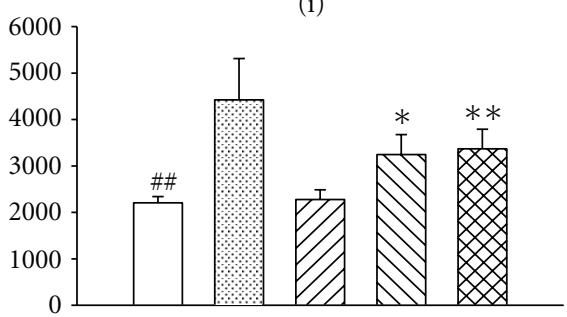

$$
\begin{aligned}
& \text { C Control } \\
& \text { Non-challenged } \\
& \text { Hesperidin-3'-O-methylether } 10 \mu \mathrm{mol} / \mathrm{kg} \text { (p.o.) } \\
& \text { Hesperidin- } 3^{\prime}-O \text {-methylether } 30 \mu \mathrm{mol} / \mathrm{kg} \text { (p.o.) } \\
& \varpi \text { Hesperidin-3'-O-methylether } 100 \mu \mathrm{mol} / \mathrm{kg} \text { (p.o.) }
\end{aligned}
$$

(j)

FIGURE 6: Effects of hesperidin (a-e) and hesperidin-3'-O-methylether $(\mathrm{f}-\mathrm{j})$ on total $\operatorname{IgE}(\mathrm{a}, \mathrm{c}, \mathrm{f}, \mathrm{and} \mathrm{h})$ and ovalbumin-specific IgE (b, d, $\mathrm{g}$, and i) levels in bronchial alveolar lavage fluid ( $\mathrm{a}, \mathrm{b}, \mathrm{f}$, and $\mathrm{g}$ ) and serum (c, d, h, i), and total $\operatorname{IgG}_{2 \mathrm{a}}(\mathrm{e}, \mathrm{j})$ levels in serum of sensitized mice which had received aerosolized methacholine $(6.25 \sim 50 \mathrm{mg} / \mathrm{mL}) 2$ days after primary allergen challenge. ${ }^{\#} P<0.05$, ${ }^{\#} P<0.01$, and ${ }^{\# \#} P<0.001$, compared to the nonchallenged group. ${ }^{*} P<0.05$ and ${ }^{* *} P<0.01$, compared to the control (vehicle) group. Each value represents the mean \pm SEM. The number of mice in each group was 10 . 


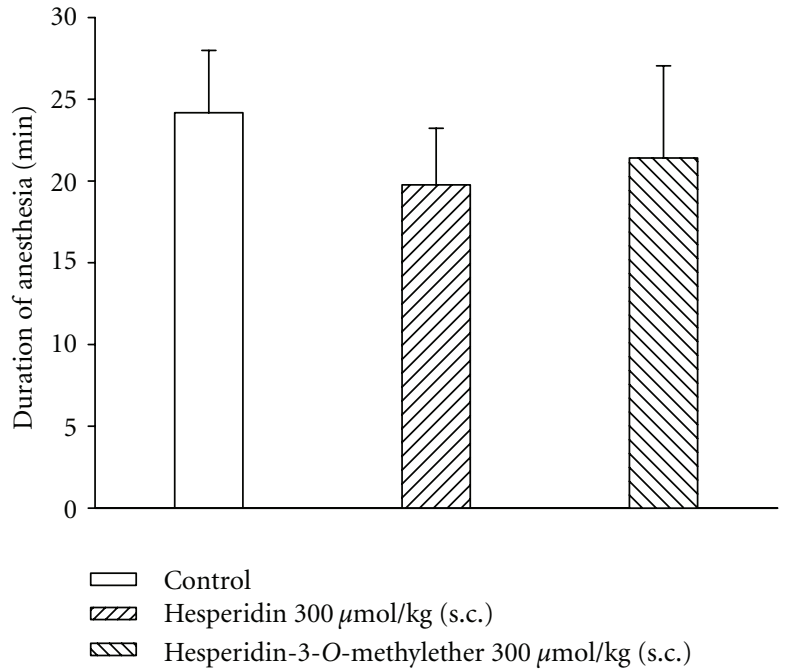

(a)

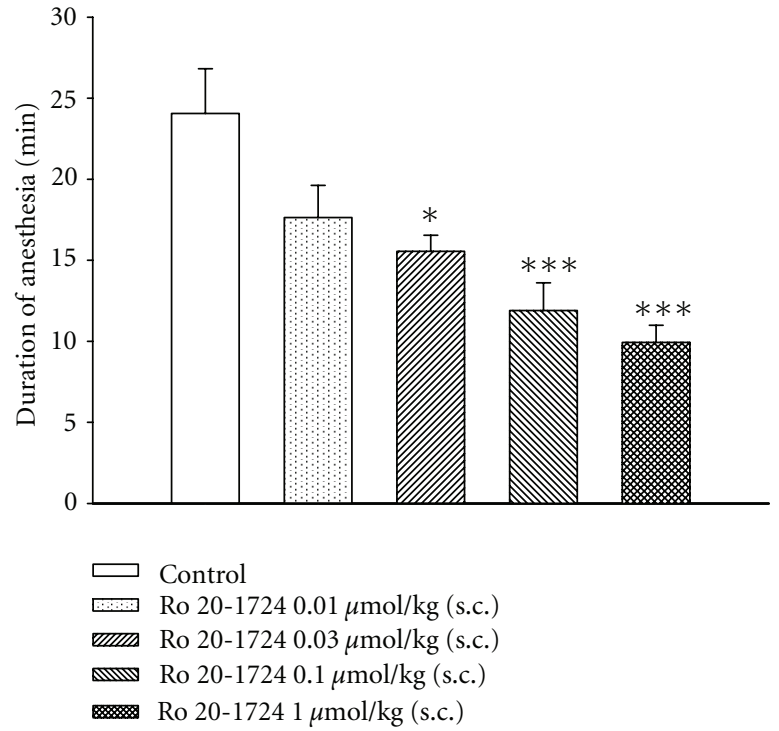

(b)

FIGURE 7: Effects of subcutaneously administered hesperidin and hesperidin-3'-O-methylether (a) and Ro 20-1724 (b) on the duration of xylazine $(10 \mathrm{mg} / \mathrm{kg}$, i.p. $) / \mathrm{ketamine}(70 \mathrm{mg} / \mathrm{kg}$, i.p.)-induced anesthesia in mice. Ro 20-1724 was administered $0.25 \mathrm{~h}$ and hesperidin and hesperidin-3'-O-methylether $1 \mathrm{~h}$ before anesthesia. ${ }^{*} P<0.05$, ${ }^{* * *} P<0.001$, compared to the vehicle (control). Each value represents the mean \pm SEM. The number of mice in each group was 10 .

and elevated IgE levels. Th2 cells, together with other inflammatory cells such as eosinophils, B cells, and mast cells are thought to play critical roles in the initiation, development, and chronicity of this disease [27]. One hypothesis emphasizes an imbalance in Th cell populations favoring expression of Th2 over Th1 cells. Cytokines released from Th2 cells are IL-4, IL-5, IL-6, IL-9, and IL-13, and those from Th1 cells are IL-2, IL-12, IFN- $\gamma$, and TNF- $\alpha[28,29]$. In the present results, hesperidin $(100 \mu \mathrm{mol} / \mathrm{kg}$, p.o. $)$ and hesperidin- $3^{\prime}-O-$ methylether $(30 \sim 100 \mu \mathrm{mol} / \mathrm{kg}$, p.o.) significantly attenuated $P_{\text {enh }}$ values at 25 and $50 \mathrm{mg} / \mathrm{mL}$ methacholine (Figures $5(\mathrm{a})$ and $5(\mathrm{~d})$ ) suggesting that it significantly suppresses AHR. At the dose of $30 \mu \mathrm{mol} / \mathrm{kg}$ (p.o.), hesperidin-3'-Omethylether, but not hesperidin, significantly suppressed AHR, suggesting that hesperidin-3'-O-methylether is more potent than hesperidin in the suppression of AHR. Similarly, hesperidin-3'-O-methylether, but not hesperidin, at the dose of $30 \mu \mathrm{mol} / \mathrm{kg}$ (p.o.) significantly suppressed the numbers of all inflammatory cells examined, including total inflammatory cells, macrophages, lymphocytes, neutrophils, and eosinophils in the BALF of mice (Figures 5(b) and 5(e)). Hesperidin-3'-O-methylether even at $10 \mu \mathrm{mol} / \mathrm{kg}$ (p.o.) significantly suppressed the level of IL-4 which are released from Th2 cells, although hesperidin at this dose did not perform in this study. However, hesperidin was reported to insignificantly inhibit the level of IL-4 at a dose of $10 \mathrm{mg} / \mathrm{kg}$ $(16.38 \mu \mathrm{mol} / \mathrm{kg}$, p.o.) in a similar animal model [13]. Thus it also suggests that hesperidin-3'-O-methylether is more potent than hesperidin in the suppression of IL-4, although the levels of IL-5 were suppressed to the same extent by both. Hesperidin-3'-O-methylether $10 \mu \mathrm{mol} / \mathrm{kg}$ (p.o.) significantly suppressed the level of IL-2, which are released from Th1 cells, although hesperidin at this dose did not perform in this study. However, hesperidin-3'-O-methylether was obviously more potent than hesperidin in inhibition of TNF- $\alpha$ level, suggesting that the former is more potent than the latter in inhibition of Th1 cells. In contrast, the levels of IFN$\gamma$ were enhanced by both hesperidin and hesperidin- $3^{\prime}-$ $O$-methylether at $100 \mu \mathrm{mol} / \mathrm{kg}$ (p.o.). These results suggest that hesperidin and hesperidin-3'-O-methylether suppress Th2 cells, and partly activate Th1 cells, which ameliorate this imbalance and produce anti-inflammatory effects. Th1 and Th2 cells have been implicated in autoimmune and atopic diseases, respectively [30]. Overall, orally administered hesperidin-3'-O-methylether was more potent than hesperidin to have anti-inflammatory effects in this in vivo study. The different potency between them may be due to their aglycons, because these two flavanone glycosides will be hydrolyzed by $\beta$-glucosidase after oral administration [31]. The aglycons of hesperidin-3'-O-methylether and hesperidin are hesperetin- $3^{\prime}-O$-methylether and hesperetin, respectively. We have reported the $\mathrm{IC}_{50}$ values of hesperetin$7,3^{\prime}$-O-dimethylether and hesperetin for PDE4 inhibition are $3.0 \mu \mathrm{M}$ [32] and $28.2 \mu \mathrm{M}$ [10], respectively, although that of hesperetin-3'-O-methylether remains unknown. Moreover, in the present results, the $\mathrm{IC}_{50}$ values of hesperidin- $3^{\prime}-\mathrm{O}$ methylether for PDE1, 3, and 4 inhibition were 13.6, 13.2, and $13.9 \mu \mathrm{M}$, respectively. Thus, that of hesperetin-3'-Omethylether for PDE4 inhibition should be less than $13.9 \mu \mathrm{M}$, because its the bulky glycosyl residue may be as a steric hindrance for binding to this PDE conformation [33]. By this reason, hesperetin is more active for PDE4 inhibition 
than hesperidin which was demonstrated to be inactive for $\mathrm{PDE} 1 \sim 5$ inhibitions in the present results. Hesperidin at $30 \mu \mathrm{mol} / \mathrm{kg}$ significantly suppressed levels of IL-2, IL4, and IL-5 (Figure 5(c)), and hesperidin-3'-O-methylether at $10 \mu \mathrm{mol} / \mathrm{kg}$ significantly suppressed levels of IL-2, IL-4, and TNF- $\alpha$ (Figure 5(f)), although all types of inflammatory cells were unaffected by both at these doses (Figures 5(b) and $5(\mathrm{e}))$. These inconsistencies may be due to the accuracies of these two measurements, because that cytokines were measured using flow cytometric methods, whereas inflammatory cells were measured using a hemocytometer under light microscopy.

IL-4 and IL-13 were shown to induce AHR in mouse asthma models $[34,35]$. IL-4 has three primary effects. First, IL-4 promotes B cell differentiation to plasma cells that secrete antigen-specific IgE antibodies. Second, IL4 promotes mast cell proliferation. Third, increased IL-4 upregulates endothelial cell expression of adhesion molecules for eosinophils [36]. IL-5 mobilizes and activates eosinophils, leading to the release of a major basic protein, cysteinylleukotriene, and eosinophil peroxidase that contribute to tissue damage and AHR $[35,37]$. Phosphoinositide 3-kinase $\delta$ $(\mathrm{p} 110 \delta)$ was shown to play a crucial role in the development, differentiation, and antigen receptor-induced proliferation of mature B cells $[38,39]$, and inhibition of $\mathrm{p} 110 \delta$ attenuates allergic airway inflammation and AHR in a murine asthma model $[38,40]$. In addition, IL-4 and IL-13 are important in directing $\mathrm{B}$ cell growth, differentiation, and secretion of IgE [41]. However, IFN- $\gamma$ released from Th1 cells preferentially directs B cell switching of $\operatorname{IgM}$ to $\operatorname{IgG}_{2 \mathrm{a}}$ and $\operatorname{IgG}_{3}$ in mice [42, 43]. In the present results, hesperidin $(100 \mu \mathrm{mol} / \mathrm{kg}$, p.o. $)$ and hesperidin-3'-O-methylether $(30 \sim 100 \mu \mathrm{mol} / \mathrm{kg}$, p.o. $)$ significantly suppressed total and OVA-specific IgE levels in the serum and BALF, and enhanced the level of total $\operatorname{IgG}_{2 a}$ in the serum of sensitized and challenged mice, suggesting that both have immunoregulatory effects. At the dose of $30 \mu \mathrm{mol} / \mathrm{kg}$ (p.o.), hesperidin-3'-O-methylether, but not hesperidin, significantly suppressed total and OVA-specific IgE levels in the serum and BALF, and enhanced the level of total $\mathrm{IgG}_{2 \mathrm{a}}$ in the serum of sensitized and challenged mice, suggesting that hesperidin-3'-O-methylether is also more potent than hesperidin in these immunoregulatory effects. 8-Methoxymethyl-3-isobutyl-1-methylxanthine, a selective PDE1 inhibitor, was reported to block lipopolysaccharide (LPS)-mediated biosynthesis of IL-6, but not to influence the TNF- $\alpha$ level. Furthermore, inhibition of PDE3 by amrinone was reported to abolish the effect of LPS on IL-6, but attenuate TNF- $\alpha$ production. Reversible competitive inhibition of PDE4 by rolipram was reported to exhibit a potent inhibitory effect on IL-6 and a dual, biphasic (excitatory/inhibitory) effect on TNF- $\alpha$ secretion [44]. Selective inhibition of PDE1, 3 , and 4 by these three compounds was also reported to exhibit a tendency to augment the translocation of NF$\kappa B_{1}$ (p50), RelA (p65), RelB (p68), and c-Rel (p75) and associate with upregulating $\mathrm{NF}-\kappa \mathrm{B}$ transcriptional activity [45]. These immunopharmacological effects may be found in the administration of hesperidin- $3^{\prime}$-O-methylether with a similar extent for PDE1, 3, and 4 inhibition.
Selective PDE4 inhibitors specifically prevent the hydrolysis of cAMP, a $3^{\prime}, 5^{\prime}$-cyclic nucleotide, and therefore have broad anti-inflammatory effects such as inhibition of cell trafficking and of cytokine and chemokine release from inflammatory cells. The increased cAMP levels induced by these selective PDE4 inhibitors subsequently activate cAMPdependent protein kinase which may phosphorylate and inhibit myosin light-chain kinase, thus inhibiting contractions [46]. The precise mechanism through which relaxation is produced by this second-messenger pathway is not known, but it may result from decreased intracellular $\mathrm{Ca}^{2+}\left(\left[\mathrm{Ca}^{2+}\right]_{i}\right)$. The decrease in $\left[\mathrm{Ca}^{2+}\right]_{i}$ may be due to reduced influx of $\mathrm{Ca}^{2+}$, enhanced $\mathrm{Ca}^{2+}$ uptake into the sarcoplasmic reticula, or enhanced $\mathrm{Ca}^{2+}$ extrusion through cell membranes [46]. Thus hesperidin-3'-O-methylether may have bronchodilatory effects and may be useful in treating COPD.

In the present in vitro studies, the $\mathrm{PDE} 4_{H} / \mathrm{PDE} 4_{L}$ ratios of hesperidin and hesperidin-3'-O-methylether were calculated to be 3 and 15.7, respectively. However, neither hesperidin nor hesperidin-3'-O-methylether administered (s.c.) influenced xylazine/ketamine-induced anesthesia. This may be due to the administration route, but administered (s.c.) hesperetin, an aglycon of hesperidin hydrolyzed after oral administration, was reported to not influence xylazine/ ketamine-induced anesthesia [47]. Nevertheless, Ro 201724, a selective PDE4 inhibitor, reversed the anesthesia. The reversing effect may occur through presynaptic $\alpha_{2}$ adrenoceptor inhibition [48], because MK-912, an $\alpha_{2}$ adrenoceptor antagonist, was reported to reverse xylazine/ ketamine-induced anesthesia in rats [8] and trigger vomiting in ferrets [48]. In contrast, clonidine, an $\alpha_{2}$-adrenoceptor agonist, prevented emesis induced by PDE4 inhibitors in ferrets [48]. The present results also suggest that hesperidin and hesperidin-3'-O-methylether may have few or no adverse effects, such as nausea, vomiting, and gastric hypersecretion. In addition, PDE4 subtypes $(\mathrm{A} \sim \mathrm{D})$ may be considered for drug development of new PDE4 inhibitors. PDE4D inhibition in nontarget tissues promotes emesis, since PDE4D knock-out mice showed reduction of xylazine/ketamine-triggered anesthesia which is used as a surrogate marker for emesis in mice, a nonvomiting species [9]. In contrast to PDE4D, selective inhibition of PDE4A and/or PDE4B in proinflammatory and immune cells is believed to evoke the therapeutically desired effects of these drugs [49]. Thus, hesperidin-3'-O-methylether did not influence xylazine/ketamine-induced anesthesia may be due to its selectivity for PDE4A and/or PDE4B inhibition(s). However, whether hesperidin-3'-O-methylether selectively inhibits the PDE4 subtype needs to be further investigated.

In conclusion, hesperidin-3'-O-methylether may be more potent than hesperidin in anti-inflammatory and immunoregulatory effects, including suppression of AHR, and reduced expressions of inflammatory cells and cytokines in the murine model of allergic asthma. In addition, neither hesperidin nor hesperidin-3'-O-methylether influenced xylazine/ketamine-induced anesthesia, suggesting that they have few or no emetic effect. Thus, hesperidin-3'-O-methylether may have more potential than hesperidin for use in treating allergic asthma and COPD. 


\section{Abbreviations}

cAMP: Adenosine $3^{\prime}, 5^{\prime}$ cyclic monophosphate

cGMP: Guanosine $3^{\prime}, 5^{\prime}$ cyclic monophosphate

COPD: Chronic obstructive pulmonary disease

DMSO: Dimethyl sulfoxide

EDTA: Ethylenediaminetetraacetic acid

HARBSs: High-affinity rolipram-binding sites

IFN: Interferon

Ig: Immunoglobulin

IL: Interleukin

PBS: $\quad$ Phosphate-buffered saline

PDE: $\quad$ Phosphodiesterase

$\mathrm{PDE}_{H}$ : High affinity for PDE4

$\mathrm{PDE}_{L}$ : $\quad$ Low affinity for PDE4

$P_{\text {enh }}$ : $\quad$ Enhanced pause

PMSF: Phenylmethanesulfonyl fluoride

Ro20-1724: 4-(3-butoxy-4-methoxybenzyl)-2imidazolidinone

TCM: $\quad$ Traditional Chinese medicine

Th: $\quad$ T-helper

TNF: Tumor necrosis factor.

\section{Conflict of Interests}

The authors declare that there is no conflict of interests.

\section{Acknowledgments}

This work was supported by a Grant (101TMU-TMUH09) from the Taipei Medical University Hospital and a Grant (NSC100-2320-B-038-031) from the National Science Council, Taipei, Taiwan.

\section{References}

[1] M. E. Lee, J. Markowitz, J. O. Lee, and H. Lee, "Crystal structure of phosphodiesterase 4D and inhibitor complex," FEBS Letters, vol. 530, no. 1-3, pp. 53-58, 2002.

[2] T. J. Torphy and L. B. Cieslinski, "Characterization and selective inhibition of cyclic nucleotide phosphodiesterase isozymes in canine tracheal smooth muscle," Molecular Pharmacology, vol. 37, no. 2, pp. 206-214, 1990.

[3] Z. Kapui, P. Schaeffer, E. G. Mikus et al., "Experimental studies on guanosine 3',5'-cyclic monophosphate levels and airway responsiveness of the novel phosphodiesterase type 5 inhibitor SR 265579 in guinea-pigs," Arzneimittel-Forschung/ Drug Research, vol. 49, no. 8, pp. 685-693, 1999.

[4] J. de Boer, A. J. Philpott, R. G. M. Van Amsterdam, M. Shahid, J. Zaagsma, and C. D. Nicholson, "Human bronchial cyclic nucleotide phosphodiesterase isoenzymes: biochemical and pharmacological analysis using selective inhibitors," British Journal of Pharmacology, vol. 106, no. 4, pp. 1028-1034, 1992.

[5] P. J. Silver, L. T. Hamel, M. H. Perrone, R. G. Bentley, C. R. Bushover, and D. B. Evans, "Differential pharmacologic sensitivity of cyclic nucleotide phosphodiesterase isozymes isolated from cardiac muscle, arterial and airway smooth muscle," European Journal of Pharmacology, vol. 150, no. 1-2, pp. 8594, 1988.

[6] E. Kim, H. O. Chun, S. H. Jung et al., "Improvement of therapeutic index of phosphodiesterase type IV inhibitors as anti-asthmatics," Bioorganic and Medicinal Chemistry Letters, vol. 13, no. 14, pp. 2355-2358, 2003.

[7] M. A. Giembycz, "Phosphodiesterase 4 inhibitors and the treatment of asthma: where are we now and where do we go from here?" Drugs, vol. 59, no. 2, pp. 193-212, 2000.

[8] A. Robichaud, C. Savoie, P. B. Stamatiou et al., "Assessing the emetic potential of PDE4 inhibitors in rats," British Journal of Pharmacology, vol. 135, no. 1, pp. 113-118, 2002.

[9] A. Robichaud, P. B. Stamatiou, S. L. C. Jin et al., "Deletion of phosphodiesterase 4D in mice shortens $\alpha_{2}$-adrenoceptormediated anesthesia, a behavioral correlate of emesis," Journal of Clinical Investigation, vol. 110, no. 7, pp. 1045-1052, 2002.

[10] W. C. Ko, C. M. Shih, Y. H. Lai, J. H. Chen, and H. L. Huang, "Inhibitory effects of flavonoids on phosphodiesterase isozymes from guinea pig and their structure-activity relationships," Biochemical Pharmacology, vol. 68, no. 10, pp. 20872094, 2004.

[11] P. Knekt, J. Kumpulainen, R. Järvinen et al., "Flavonoid intake and risk of chronic diseases," American Journal of Clinical Nutrition, vol. 76, no. 3, pp. 560-568, 2002.

[12] K. Y. Yen, Pharmacology of Common Chinese Medicine (III), National Research Institute of Chinese Medicine, Taipei, Taiwan, 1971.

[13] D. Wei, X. Ci, X. Chu, M. Wei, S. Hua, and X. Deng, "Hesperidin suppresses ovalbumin-induced airway inflammation in a mouse allergic asthma model," Inflammation, pp. 1-8, 2011.

[14] W. C. Ko, M. C. Chen, S. H. Wang, Y. H. Lai, J. H. Chen, and C. N. Lin, "3-O-methylquercetin more selectively inhibits phosphodiesterase subtype 3," Planta Medica, vol. 69, no. 4, pp. 310-315, 2003.

[15] W. J. Thompson and M. M. Appleman, "Multiple cyclic nucleotide phosphodiesterase activities from rat brain," Biochemistry, vol. 10, no. 2, pp. 311-316, 1971.

[16] H. S. Ahn, W. Crim, M. Romano, E. Sybertz, and B. Pitts, "Effects of selective inhibitors on cyclic nucleotide phosphodiesterase of rabbit aorta," Biochemical Pharmacology, vol. 38, no. 19, pp. 3331-3339, 1989.

[17] T. Podzuweit, P. Nennstiel, and A. Muller, "Isozyme selective inhibition of cGMP-stimulated cyclic nucleotide phosphodiesterases by erythro-9-(2-hydroxy-3-nonyl) adenine," Cellular Signalling, vol. 7, no. 7, pp. 733-738, 1995.

[18] S. A. Harrison, D. H. Reifsnyder, and B. Gallis, "Isolation and characterization of bovine cardiac muscle cGMP-inhibited phosphodiesterase: a receptor for new cardiotonic drugs," Molecular Pharmacology, vol. 29, no. 5, pp. 506-514, 1986.

[19] M. L. Reeves, B. K. Leigh, and P. J. England, “The identification of a new cyclic nucleotide phosphodiesterase activity in human and guinea-pig cardiac ventricle. Implications for the mechanism of action of selective phosphodiesterase inhibitors," Biochemical Journal, vol. 241, no. 2, pp. 535-541, 1987.

[20] P. G. Gillespie and J. A. Beavo, "Inhibition and stimulation of photoreceptor phosphodiesterases by dipyridamole and $\mathrm{M}$ and B 22,948," Molecular Pharmacology, vol. 36, no. 5, pp. 773$781,1989$.

[21] H. H. Schneider, R. Schmiechen, M. Brezinski, and J. Seidler, "Stereospecific binding of the antidepressant rolipram to brain protein structures," European Journal of Pharmacology, vol. 127, no. 1-2, pp. 105-115, 1986.

[22] Y. Zhao, H. T. Zhang, and J. M. O'Donnell, "Inhibitor binding to type 4 phosphodiesterase (PDE4) assessed using $\left[{ }^{3} \mathrm{H}\right]$ piclamilast and $\left[{ }^{3} \mathrm{H}\right]$ rolipram," Journal of Pharmacology and Experimental Therapeutics, vol. 305, no. 2, pp. 565-572, 2003. 
[23] A. Kanehiro, T. Ikemura, M. J. Mäkelä et al., "Inhibition of phosphodiesterase 4 attenuates airway hyperresponsiveness and airway inflammation in a model of secondary allergen challenge," American Journal of Respiratory and Critical Care Medicine, vol. 163, no. 1, pp. 173-184, 2001.

[24] E. Hamelmann, J. Schwarze, K. Takeda et al., "Noninvasive measurement of airway responsiveness in allergic mice using barometric plethysmography," American Journal of Respiratory and Critical Care Medicine, vol. 156, no. 3, pp. 766-775, 1997.

[25] G. E. Winterrowd and J. E. Chin, "Flow cytometric detection of antigen-specific cytokine responses in lung $\mathrm{T}$ cells in a murine model of pulmonary inflammation," Journal of Immunological Methods, vol. 226, no. 1-2, pp. 105-118, 1999.

[26] B. N. Melgert, D. S. Postma, M. Geerlings et al., "Shortterm smoke exposure attenuates ovalbumin-induced airway inflammation in allergic mice," American Journal of Respiratory Cell and Molecular Biology, vol. 30, no. 6, pp. 880-885, 2004.

[27] W. W. Busse and R. F. Lemanske, "Asthma," New England Journal of Medicine, vol. 344, no. 5, pp. 350-362, 2001.

[28] H. Revets, G. Pynaert, J. Grooten, and P. De Baetselier, "Lipoprotein I, a TLR2/4 ligand modulates Th2-driven allergic immune responses," Journal of Immunology, vol. 174, no. 2, pp. 1097-1103, 2005.

[29] A. Vojdani and J. Erde, "Regulatory T cells, a potent immunoregulatory target for CAM researchers: the ultimate antagonist (I)," Evidence-based Complementary and Alternative Medicine, vol. 3, no. 1, pp. 25-30, 2006.

[30] D. J. Cher and T. R. Mosmann, "Two types of murine helper $\mathrm{T}$ cell clone. II. Delayed-type hypersensitivity is mediated by Th1 clones," Journal of Immunology, vol. 138, no. 11, pp. 36883694, 1987.

[31] V. D. Bokkenheuser, C. H. L. Shackleton, and J. Winter, "Hydrolysis of dietary flavonoid glycosides by strains of intestinal Bacteroides from humans," Biochemical Journal, vol. 248, no. 3, pp. 953-956, 1987.

[32] Y. L. Yang, H. T. Hsu, K. H. Wang et al., "Hesperetin7,3'-O-dimethylether selectively inhibits phosphodiesterase 4 and effectively suppresses ovalbumin-induced airway hyperresponsiveness with a high therapeutic ratio," Journal of Biomedical Science, vol. 18, no. 1, p. 84, 2011.

[33] S. Y. Namgoong, K. H. Son, H. W. Chang, S. S. Kang, and H. P. Kim, "Effects of naturally occurring flavonoids on mitogeninduced lymphocyte proliferation and mixed lymphocyte culture," Life Sciences, vol. 54, no. 5, pp. 313-320, 1994.

[34] C. Taube, C. Duez, Z. H. Cui et al., "The role of IL-13 in established allergic airway disease," Journal of Immunology, vol. 169, no. 11, pp. 6482-6489, 2002.

[35] B. B. Vargaftig and M. Singer, "Leukotrienes mediate murine bronchopulmonary hyperreactivity, inflammation, and part of mucosal metaplasia and tissue injury induced by recombinant murine interleukin-13," American Journal of Respiratory Cell and Molecular Biology, vol. 28, no. 4, pp. 410-419, 2003.

[36] J. Tucker, C. H. Fanta et al., "Integrative inflammation pharmacology: asthma," in Principles of Pharmacology the Pathophysiologic Basis of Drug Therapy, D. E. Golan, Ed., pp. 695-705, Lippincott Williams \& Wilkins, Philadelphia, Pa, USA, 2005.

[37] P. S. Foster, S. P. Hogan, A. J. Ramsay, K. I. Matthaei, and I. G. Young, "Interleukin 5 deficiency abolishes eosinophilia, airways hyperreactivity, and lung damage in a mouse asthma model," Journal of Experimental Medicine, vol. 183, no. 1, pp. 195-201, 1996.
[38] E. Clayton, G. Bardi, S. E. Bell et al., "A crucial role for the $\mathrm{p} 110 \delta$ subunit of phosphatidylinositol 3-kinase in B cell development and activation," Journal of Experimental Medicine, vol. 196, no. 6, pp. 753-763, 2002.

[39] K. Okkenhaug, A. Bilancio, G. Farjot et al., "Impaired B and $\mathrm{T}$ cell antigen receptor signaling in p110 $\delta$ PI 3-kinase mutant mice," Science, vol. 297, no. 5583, pp. 1031-1034, 2002.

[40] K. S. Lee, H. K. Lee, J. S. Hayflick, Y. C. Lee, and K. D. Puri, "Inhibition of phosphoinositide 3-kinase $\delta$ attenuates allergic airway inflammation and hyperresponsiveness in murine asthma model," FASEB Journal, vol. 20, no. 3, pp. 455-465, 2006.

[41] C. L. Emson, S. E. Bell, A. Jones, W. Wisden, and A. N. J. McKenzie, "Interleukin (IL)-4-independent induction of immunoglobulin (Ig)E, and perturbation of $\mathrm{T}$ cell development in transgenic mice expressing IL-13," Journal of Experimental Medicine, vol. 188, no. 2, pp. 399-404, 1998.

[42] C. M. Snapper, K. B. Marcu, and P. Zelazowski, "The immunoglobulin class switch: beyond 'accessibility'” Immunity, vol. 6, no. 3, pp. 217-223, 1997.

[43] J. Stavnezer, "Molecular processes that regulate class switching," Current Topics in Microbiology and Immunology, vol. 245, pp. 127-168, 1999.

[44] J. J. Haddad, S. C. Land, W. O. Tarnow-Mordi, M. Zembala, D. Kowalczyk, and R. Lauterbach, "Immunopharmacological potential of selective phosphodiesterase inhibition. I. Differential regulation of lipopolysaccharide-mediated proinflammatory cytokine (interleukin-6 and tumor necrosis factor- $\alpha$ ) biosynthesis in alveolar epithelial cells," Journal of Pharmacology and Experimental Therapeutics, vol. 300, no. 2, pp. 559566, 2002.

[45] J. J. Haddad, S. C. Land, W. O. Tarnow-Mordi, M. Zembala, D. Kowalczyk, and R. Lauterbach, "Immunopharmacological potential of selective phosphodiesterase inhibition. II. Evidence for the involvement of an inhibitory- $\kappa \mathrm{B} /$ nuclear factor$\kappa \mathrm{B}$-sensitive pathway in alveolar epithelial cells," Journal of Pharmacology and Experimental Therapeutics, vol. 300, no. 2, pp. 567-576, 2002.

[46] D. P. Westfall, W. T. Gerthoffer, and R. C. Webb, "Vasodilators and nitric oxide synthasein," in Human Pharmacology Molecular to Clinical, T. M. Brody, J. Larner, and K. P. Minneman, Eds., pp. 239-247, Mosby, St. Louis, Mo, USA, 1998.

[47] C. H. Shih, L. H. Lin, H. T. Hsu et al., "Hesperetin, a selective phosphodiesterase 4 inhibitor, effectively suppresses ovalbumin-induced airway hyperresponsiveness without influencing xylazine/ketamine-induced anesthesia," EvidenceBased Complementary and Alternative Medicine, vol. 2012, Article ID 472897, 10 pages, 2012.

[48] A. Robichaud, C. Savoie, P. B. Stamatiou, F. D. Tattersall, and C. C. Chan, "PDE4 inhibitors induce emesis in ferrets via a noradrenergic pathway," Neuropharmacology, vol. 40, no. 2, pp. 262-269, 2001.

[49] S. L. Jin, W. Richter, and M. Conti, "Insights into the physiological functions of PDE4 from knockout mice," in Cyclic Nucleotide Phosphodiesterases in Health and Disease, J. A. Beavo, S. H. Francis, and M. D. Houslay, Eds., pp. 323-346, CRC Press, Boca Raton, Fla, USA, 2007. 


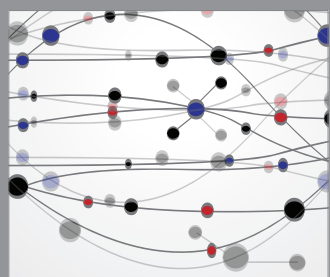

The Scientific World Journal
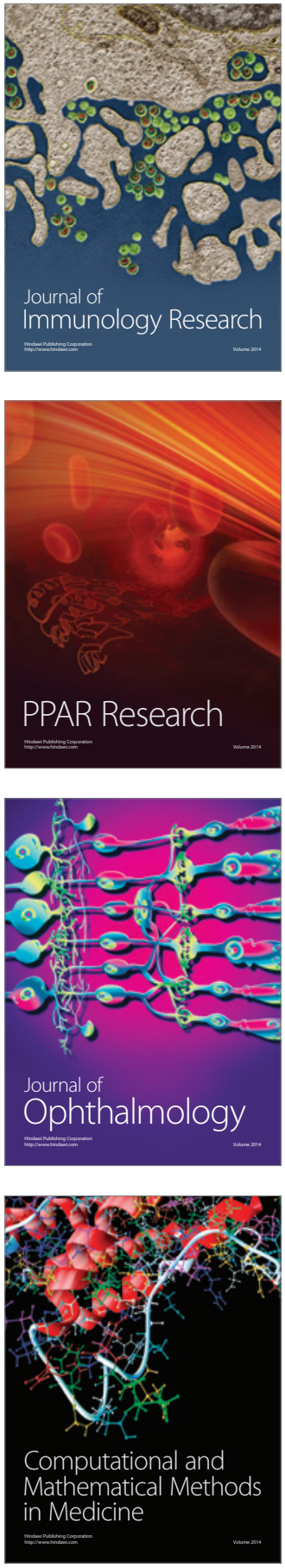

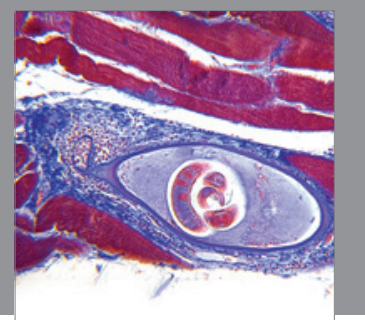

Gastroenterology

Research and Practice
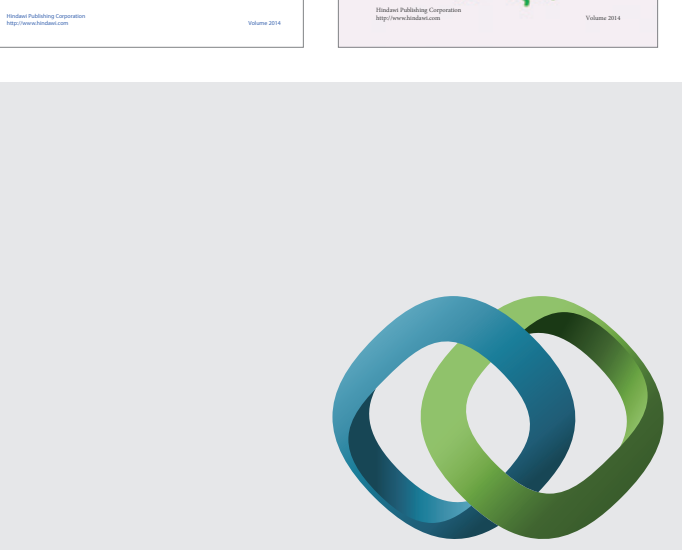

\section{Hindawi}

Submit your manuscripts at

http://www.hindawi.com
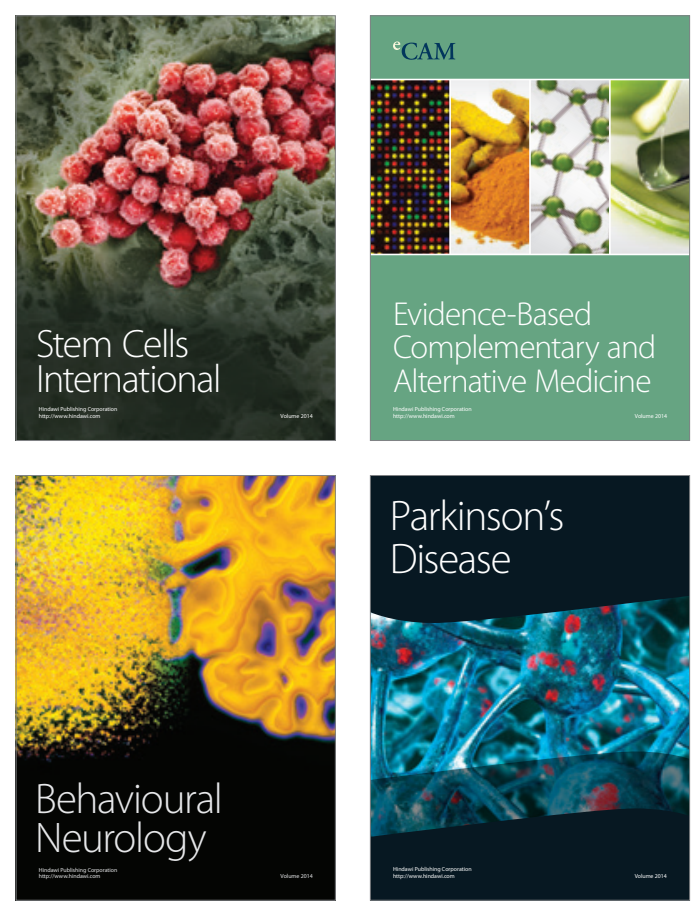

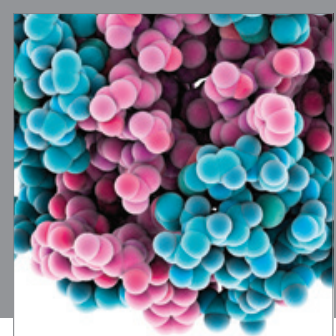

Journal of
Diabetes Research

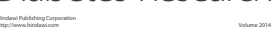

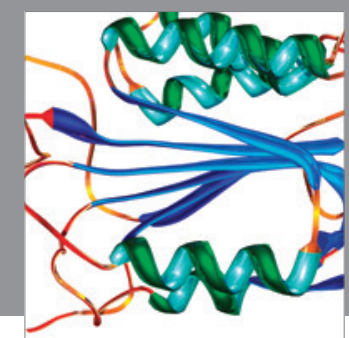

Disease Markers
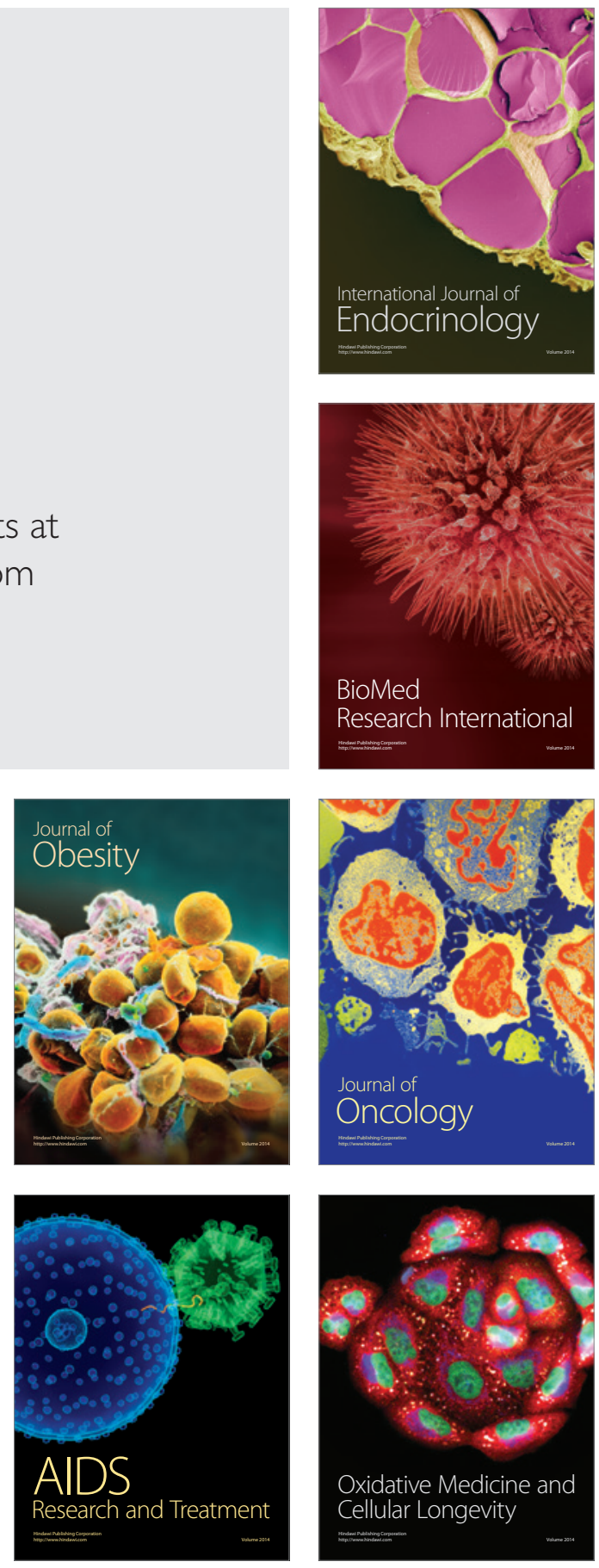